IZA DP No. 9729

Job Loss and Immigrant Labor Market Performance

Bernt Bratsberg

Oddbjørn Raaum

Knut Røed

February 2016

Forschungsinstitut

zur Zukunft der Arbeit

Institute for the Study

of Labor 


\title{
Job Loss and \\ Immigrant Labor Market Performance
}

\author{
Bernt Bratsberg \\ Ragnar Frisch Centre for Economic Research \\ Oddbjørn Raaum \\ Ragnar Frisch Centre for Economic Research \\ and IZA \\ Knut Røed \\ Ragnar Frisch Centre for Economic Research \\ and IZA
}

\section{Discussion Paper No. 9729 \\ February 2016}

\author{
IZA \\ P.O. Box 7240 \\ 53072 Bonn \\ Germany \\ Phone: +49-228-3894-0 \\ Fax: +49-228-3894-180 \\ E-mail: iza@iza.org
}

\begin{abstract}
Any opinions expressed here are those of the author(s) and not those of IZA. Research published in this series may include views on policy, but the institute itself takes no institutional policy positions. The IZA research network is committed to the IZA Guiding Principles of Research Integrity.

The Institute for the Study of Labor (IZA) in Bonn is a local and virtual international research center and a place of communication between science, politics and business. IZA is an independent nonprofit organization supported by Deutsche Post Foundation. The center is associated with the University of Bonn and offers a stimulating research environment through its international network, workshops and conferences, data service, project support, research visits and doctoral program. IZA engages in (i) original and internationally competitive research in all fields of labor economics, (ii) development of policy concepts, and (iii) dissemination of research results and concepts to the interested public.
\end{abstract}

IZA Discussion Papers often represent preliminary work and are circulated to encourage discussion. Citation of such a paper should account for its provisional character. A revised version may be available directly from the author. 
IZA Discussion Paper No. 9729

February 2016

\section{ABSTRACT}

\section{Job Loss and Immigrant Labor Market Performance*}

While integration policies typically focus on labor market entry, we present evidence showing that immigrants from low-income countries tend to have more precarious jobs, and face more severe consequences of job loss, than natives. For immigrant workers in the Norwegian private sector, the probability of job loss in the near future is twice that of native workers. Using corporate bankruptcy for identification, we find that the adverse effects of job loss on future employment and earnings are more than twice as large for immigrant employees.

JEL Classification: F22, H55, J24, J65

Keywords: migration, job loss, firm closure, unemployment

Corresponding author:

Bernt Bratsberg

The Ragnar Frisch Centre for Economic Research

Gaustadalléen 21

0349 Oslo

Norway

E-mail: bernt.bratsberg@frisch.uio.no

\footnotetext{
* We are grateful to Taryn Galloway and Sverre Try for valuable comments. We acknowledge funding from the Ministry of Labour (project "Immigrant Employment Profiles") and the Norwegian Research Council (projects "European Strains" and "Work Life Challenges"). The paper is part of the research activities of the Centre for the Study of Equality, Social Organization, and Performance, University of Oslo. Data made available by Statistics Norway have been essential for this research.
} 


\section{Introduction}

The recent waves of refugees and asylum seekers to Europe have placed immigration and integration issues at the top of the policy agenda. With successful labor market integration, high rates of immigration may actually be a welcome solution to the demographic and fiscal challenges facing many countries. As argued by the $O E C D$, although there will obviously be short-term costs arising from the current refugee surge, “... there will also be sizeable economic and public finance benefits, provided that refugees are integrated into the labor market" (OECD, 2015a, p. 1). Historical experiences, however, point to a considerable risk of failure in the integration process. Today, employment rates of foreignborn are below those of natives in virtually all European countries (OECD, 2015b, p.85), and immigrants are overrepresented among beneficiaries of non-contributory transfers in countries with generous welfare programs (Boeri, 2010). Such outcomes are not isolated to refugees and immigrants granted political asylum. Empirical studies of labor migrants from developing countries have documented disturbingly short work careers with a disproportional dependency on social insurance benefits despite an initial period of very high employment rates (Bratsberg et al., 2010; 2014).

Why have many of the immigrants moving from low-income to high-income countries performed so poorly in the labor market over the longer run? Studies of immigrant labor market performance highlight the roles of skills in terms of educational attainment, language competency and literacy, as well as discrimination and ethnicity-related preferences (Trejo, 2003; Bleakley and Chin, 2004; Ferrer et al., 2006; Carlsson and Rooth, 2007). Existing empirical evidence also reveals that cyclical fluctuations play an important role (Barth et al., 2004; Bratsberg et al., 2006; Dustmann et al., 2010). Immigrants often find employment in industries characterized by large cyclical fluctuations and the widespread practice of last-in-first-out principles implies that immigrants tend to be among the first to be laid off during economic downturns. Given that social insurance entitlements in a welfare state typically exceed potential wage earnings in the origin country, immigrants from low-income source countries also have weak incentives to return migrate should they lose their job. Indeed, recent evidence shows that the immigrant-native unemployment gap widened throughout the European Union during the financial crisis, and surveys indicate that immigrants are more prone to experience involuntary inactivity, as, among the non-employed, a higher proportion of immigrants than natives report that they are willing to work (OECD, 2015b). In the United States, Hoynes et al. (2012) document significant differences across demographic groups in the impact of the Great Recession. 
The purpose of the present paper is to examine short and long-term impacts of job loss for immigrants from poor and rich source countries, and compare such impacts to those of natives. Labor market outcomes of immigrants may be more sensitive to the economic cycle than those of natives either because immigrants happen to work in more closure-exposed firms, occupations, and industries, or because job displacement has particularly severe impacts on their subsequent patterns of employment and earnings. There is now a large international literature examining the individual consequences of job loss (see, e.g., Hamermesh, 1987; Ruhm, 1991; Jacobson et al., 1993; Neal, 1995; Kletzer, 1998; and Hallock, 2009), including three recent studies based on Norwegian register data (Rege et al., 2009; Huttunen et al., 2011; Bratsberg et al., 2013). The basic idea pursued in several of these papers is to examine the impacts of observed job separations that can arguably be considered exogenous with respect to the characteristics of each individual worker, such as displacements due to large downsizings or firm closures. The present paper continues along this track and focuses on workers in firms that drastically reduce their staff or close down because of bankruptcy. We are both interested in examining the extent to which immigrants and natives have different exposure rates to these kinds of adverse shocks, and the possibly differential impacts of such shocks on subsequent spells of non-employment and/or earnings. The consequences of job loss may well be more severe for immigrants as they possess less general human capital directly applicable in the host-country labor market and have inferior majority language skills, social capital and networks compared to natives (Dustmann et al., 2015). Some immigrants are recruited to specific jobs where mastery of the native language is of minor importance, often in periods of high labor demand. In the search for new employment following displacement, and in less fortunate economic circumstances, such disadvantages are expected to create barriers to landing a new job.

Our evidence reveals that, compared to natives, migrants from developing countries (LDC) are more likely to work in firms that are going to scale down or close down during the next few years. In our data, their observed "overexposure" to major downsizing and closure events over a three-year period is roughly 50 percent. We also find that the adverse consequences of being exposed to such events - in form of lower subsequent employment and earnings - are significantly larger for LDC migrants than for natives. In contrast, migrants from western European countries (EEA) exhibit very similar patterns to those of natives, both in terms of exposure and effects. The one exception is outmigration: EEA migrants are more likely than other groups to leave the country if their employer goes bankrupt or reduces the workforce considerably. 
The results also speak to the role of job loss in general. While exogenous job separations play an important role in theoretical models of unemployment, there are few data sources with information on why job spells end. By combining inflow rates to registered unemployment across groups of workers, both with and without exposure to firm closure events, with the effects of bankruptcy as a measure of the job loss effect, we estimate the importance of job loss for the observed gaps between natives and immigrants in employment change and earnings growth. Comparing LDC migrants to natives, the combination of higher job loss rates and more severe effects of job loss accounts for about 60 percent of their higher three-year transition rate out of employment.

Taken together, the evidence shows that worker sorting across firms has important implications for immigrant-native employment and earnings gaps, as immigrants are more exposed to exogenous job separations and because the effects of job loss are more severe for immigrants from developing countries than for other workers.

\section{Background and data}

Each year, approximately ten percent of all private-sector jobs in Norway are destructed (Salvanes, 1997; Bratsberg et al., 2013). These events do not occur randomly, however. Some firms and some workers are much more likely to be exposed to job loss than others are. While the role of firm heterogeneity has been emphasized in recent studies of wage inequality (e.g., Card et al., 2013) and immigrant-native wage differences (Aydemir and Skuterud, 2008; Barth et al., 2012), there is little evidence on the importance of immigrant job allocation across firms when it comes to employment shocks. Yet, the mechanisms behind the observed underrepresentation of immigrants in high-pay firms are likely to generate a similar overexposure to firm downsizing and bankruptcy.

Integration policies targeted at refugees and family immigrants typically focus on facilitating a first foothold in the host-country labor market. While this is clearly a necessary and important ingredient of a successful assimilation process, it may not be sufficient. If the first job is a poor job, in the sense that it comes with a high risk of quick elimination, it will not represent the intended ladder of opportunity into the regular labor market. Instead, the job may build up entitlements to unemployment and disability insurances, and thus lay the foundation for cycles of social insurance dependency and poor and precarious jobs. 
Tentative evidence that job loss may be prominent and hamper the labor market assimilation of immigrants from low-income source countries appears in Figure 1. The figure traces out employment profiles by years since arrival for the two groups of immigrants from poor and rich countries that will form the focus of our empirical analyses below. The first group consists of immigrants from developing countries (LDC). This group comprises labor and family migrants from Pakistan and Turkey, and refugees, asylum seekers, and family migrants from Vietnam, Bosnia, Sri Lanka, Iraq, Iran, Chile, Kosovo, and Somalia - the 10 major low-income source countries in the immigrant labor force during our study period. The second group is immigrants from western European countries (EEA). Labor immigrants from

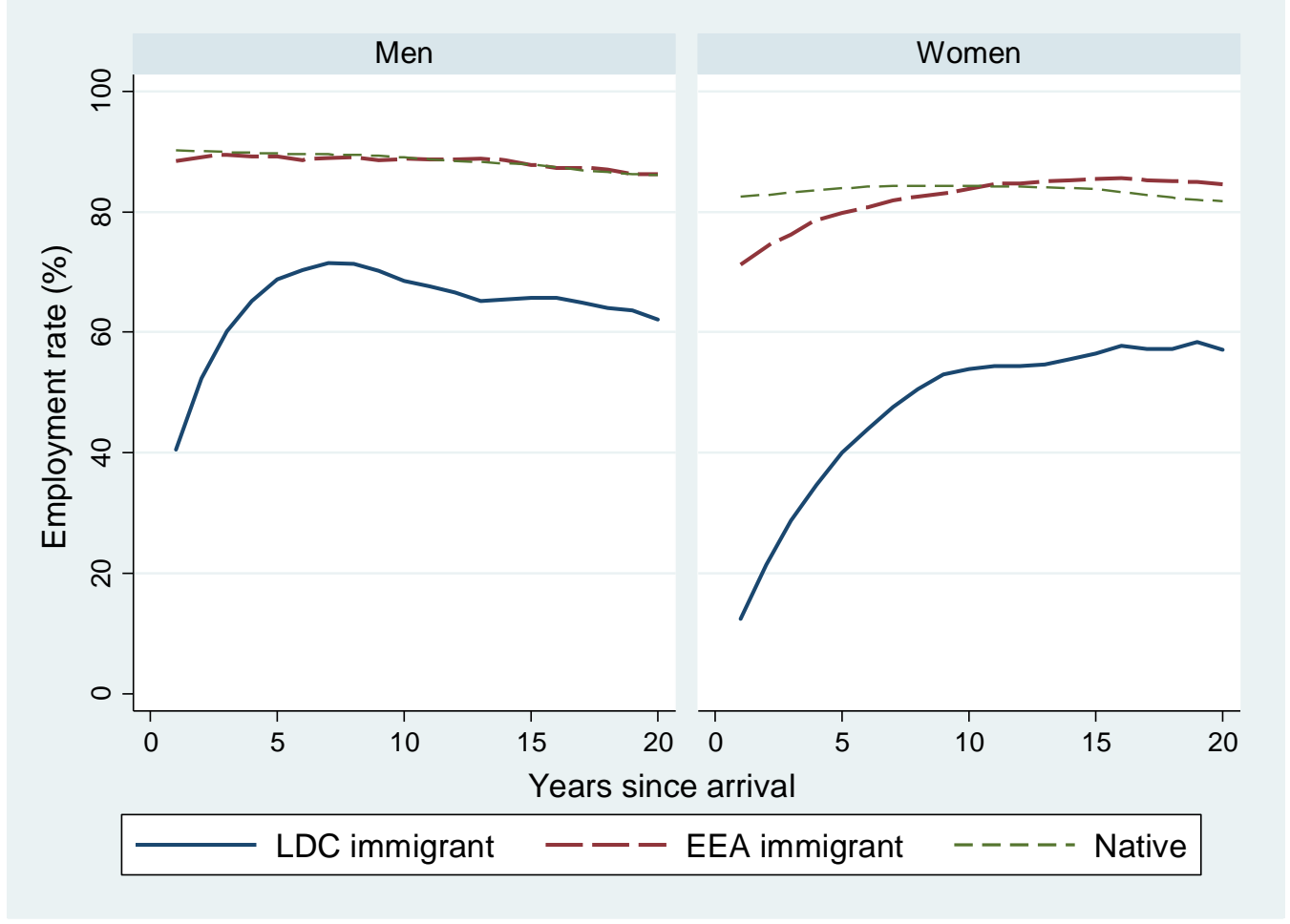

Figure 1. Immigrant employment profiles

Note: Employment is for each year defined as having annual labor earnings exceeding the base amount of the Norwegian pension system (corresponding to approximately $17 \%$ of average full-time full-year earnings). Immigrant samples are restricted to those 18-47 years of age at arrival who entered between 1990 and 2010 and stayed for at least 5 years. Employment rates are computed for those 25-64 and residing in Norway at the end of the year. The observation period is 1991-2013. Native samples are stratified so that the frequency distribution of age and year of observation matches that of immigrants by gender and years since arrival. 
Sweden, Denmark, the UK, and Germany dominate this group. ${ }^{1}$ To place the immigrant profiles in perspective, we have also plotted the average employment rate for natives stratified so that each point has the exact same frequency distribution of age and year of observation as the corresponding yearssince-arrival and gender cell of immigrants.

As the figure shows, employment rates of male EEA immigrants are indistinguishable from those of native men while the profile of female EEA immigrants exhibits classic assimilation features whereby immigrants start below natives, but have faster growth rates and overtake native levels after ten years in the country. For both male and female LDC immigrants, a group dominated by refugees, the employment profile shows an encouraging pattern of rapid labor market assimilation during the initial period, but also that the assimilation process appears to be exhausted after a few years, at which point the employment gap relative to natives is far from closed. In fact, eight years after entry, the employment rate of LDC men is 18 percentage points below that of native men (72 versus 90 percent), and employment of LDC women 36 percentage points below that of native women of the same age (48 versus 84 percent). A second striking feature of Figure 1 is that, after the initial period of rising employment, the employment rate of LDC men falls with time in the country, from 72 percent eight years after entry to 62 percent 20 years after entry. As such, following an early period of labor market integration, the tentative evidence points to a long-term pattern of "dissimilation" with declining employment rates.

In the present paper, we do not study the mechanisms that help newly arrived immigrants into employment. To the contrary, we focus entirely on cases where employment has indeed been found, and examine the mechanisms by which it is again lost. Employment may be lost for several reasons. A worker may quit voluntarily, a temporary job contract may come to its end, the firm may reorganize or scale down on the number of employees, or the employer may lay off workers due to disagreement or misdemeanor. In this paper, we are primarily interested in involuntary job loss, with a focus on immigrant-native differentials in exposure to and long-term effects of such events.

The data we use are collected from administrative registers and contain longitudinal information on employment, earnings, and unemployment insurance program participation. Our analysis is going to be conditioned on employment in a private-sector firm in at least one year during the period from 1994 to

\footnotetext{
${ }^{1}$ The sample does not include the recent wave of labor migrants for Eastern Europe, as our methodological design, whereby we track workers in the labor market for up to ten years, entails that the vast majority of the recent cohort would have been dropped from the analyses.
} 
2010. We divide the population of workers into three groups based on country of origin - the LDC and EEA immigrant groups described above and natives, i.e., persons born in Norway to two Norwegian-born parents. While we use complete population data for the two immigrant groups, we use a 10 percent random sample of natives. In order to align the lifecycle stages of the various groups in the descriptive analyses, we have stratified the native comparison groups by age to match the distribution among immigrants.

Figure 2 illustrates the key phenomenon we address. Starting from a base year of conditioned employment, the figure shows for all three demographic groups (LDC immigrants, EEA immigrants, and natives) - and separately for men and women - the fraction that remains employed (in any job) in subsequent years. The differences that materialize between the three groups are striking: While natives

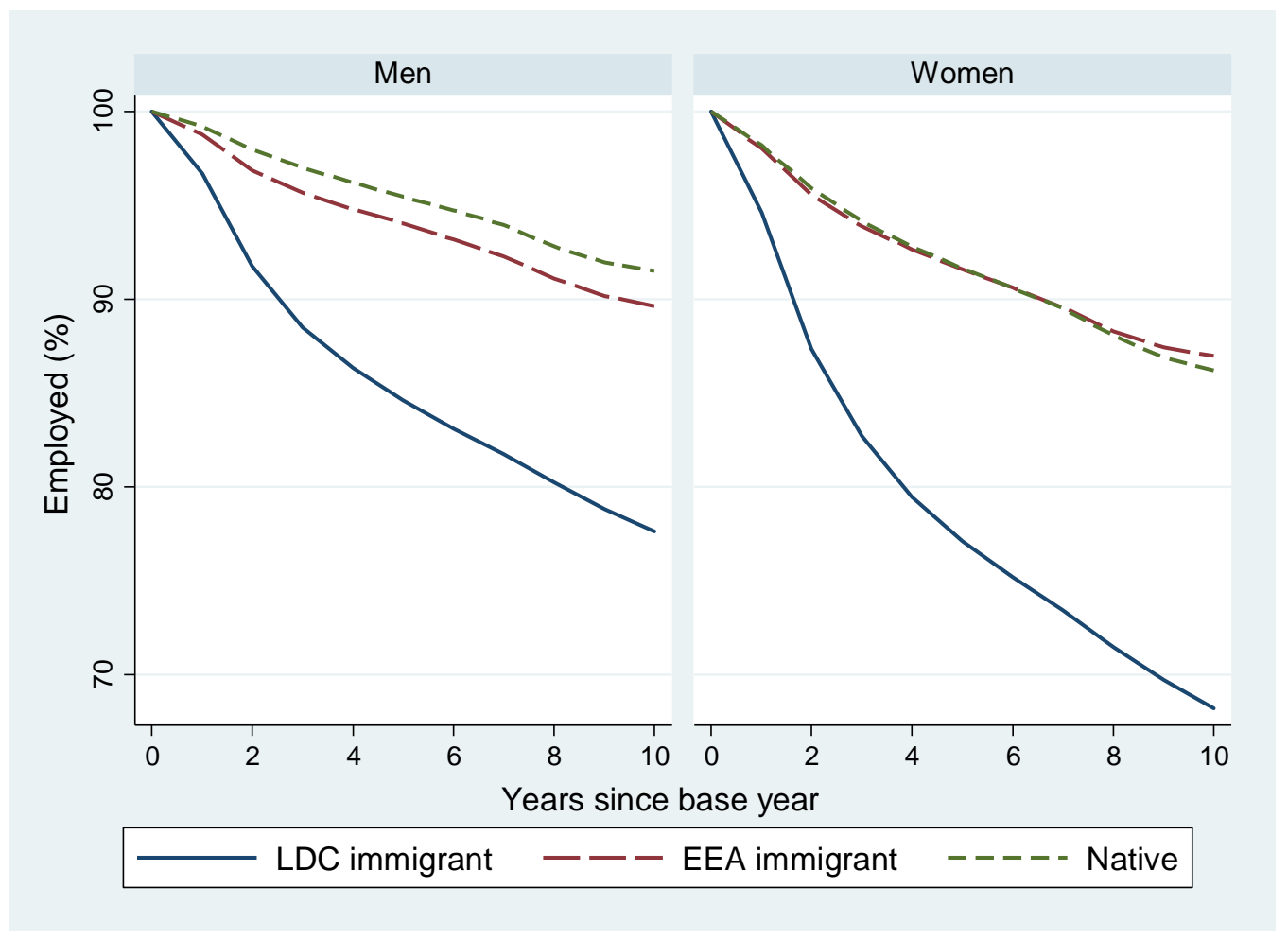

Figure 2. Percent employed 1-10 years after conditioned employment

Note: Samples comprise private-sector workers aged 25-54 in the base year of conditioned employment (year 0). Annual observations are included for those still residing in Norway at the end of the year in question. Each person may contribute with several base-year and subsequent (overlapping) employment observations. See also note to Figure 1. 
and EEA immigrants have similar employment profiles (particularly for women), with employment rates close to or higher than 90 percent throughout the ten year period after the base year, the employment rates of LDC immigrants drop sharply and end up well below 80 percent for men and 70 percent for women. Such differences show that the lower employment rates of LDC immigrants revealed by Figure 1 not only reflect lower entry rates, but also higher transition rates out of employment. The overall declining employment rates in Figure 2 reflect "mean-reversion" caused by out-of-employment transitions, including those motivated changed labor supply preferences or working conditions.

The prime purpose of our empirical analysis is to assess the role that involuntary job separations play in explaining these employment differences. Involuntary job loss may explain the immigrant-native differential through differences in exposure or through differences in the consequence of such exposure. Distinguishing involuntary from voluntary separations based on administrative register data is not a trivial task, however. It is likely that a large fraction of workers who lose their job will find a new one without ever disclosing the involuntary nature of the job loss by registering as an unemployed job seeker. And the distinction between voluntary and involuntary job separations may in many cases be a bit blurred, for example in cases where a manager encourages employees to quit.

Our strategy will be to identify the causal effects of involuntary job loss primarily based on some admittedly rather rare events, namely cases where the employer goes bankrupt. Although infrequent, these events have, from a research point of view, the great advantage of causing almost indisputably involuntary job loss. The typical approach to studying effects of job loss compares displaced workers to colleagues who retained their job (Jacobson et al., 1993; Couch and Placzek, 2010) or to workers in other firms (Huttunen et al., 2011). As layoffs can be selective with respect to worker characteristics, studies typically focus on major downsizings. ${ }^{2}$ To avoid bias from non-random layoffs, we follow Rege et al. $(2009 ; 2011)$ and classify workers according to the downsizing and closure status of their firm rather than according to individual worker displacement, focusing on closures due to bankruptcy and events where firms drastically reduce their staff. In the case of mass layoffs, we define all workers as affected, like in an intention-to-treat framework.

The empirical study consists of three parts. First, we examine the extent to which immigrants more than natives tend to work in firms exposed to major downsizing and closure events. Second, we analyze the

\footnotetext{
${ }^{2}$ As noted by Jacobson et al., 1993, p.696: "However, we can substantially lessen the importance of this selectivity bias by restricting the analysis to workers who separate from firms that close all or a large part of their operations. Such workers are unlikely to have left their jobs as a result of their own poor performance. Therefore, in the empirical work we give greater weight to the estimated earnings loss of workers in our mass-layoff sample."
} 
causal impacts of such events for immigrants and native workers, with a focus on subsequent employment and earnings outcomes. Towards the end, we generalize our findings from these rare events to the broader labor market by first backing out the implied relationship between exogenous job loss and the probability of becoming unemployed, and then use this relationship to estimate the total number of job losses and the overall impact on subsequent employment and earnings growth.

\section{Exposure to adverse firm employment shocks}

To investigate immigrant and native exposure to firm-specific displacement shocks, our starting point is workers 25 to 55 years of age who in some year $t=1994, \ldots, 2010$ are employed in a private sector firm that may or may not be subjected to a major downsizing event or closure during the upcoming years. We define displacement shocks on a firm-year basis as either a downsizing of the number of employees by at least 60 percent, without filing for bankruptcy, or a downsizing by 100 percent in combination with a subsequent bankruptcy filing. ${ }^{3}$ Register-based analyses of downsizing events will invariably identify a number of "spurious" downsizings and closures, caused by restructuring (e.g., a merger or a demerger) that cannot be disentangled from genuine mass layoffs. As shown in Bratsberg et al. (2013), focusing on bankruptcies almost eliminates this problem; hence, although bankruptcies account for a small share of layoffs, this event is a useful as non-contaminated indicator of genuine mass layoff.

Table 1 shows the extent to which the three groups of workers work in firms that will undergo such adverse events in the near future. More specifically, we look at the incidence of downsizings (by at least $60 \%)$ and closures over a three-year period. The reason why we use a three-year perspective here rather than focusing on, say, downsizings and closures occurring the next year only, is that we expect a considerable sorting process to take place over a period prior to downsizing and closure events, as workers start to leave the presumed "sinking ship". Including events that occur longer into the future reduces - though does not entirely solve - this potential selection problem. This improvement comes at a cost, however, as additional measurement error is introduced by the fact that some of the workers assumed to be exposed to the adverse employment shock in reality will have left the firm well before realization of the shock (for reasons unrelated to the forthcoming downsizing or closure).

\footnotetext{
${ }^{3}$ Specifically, we define a major downsizing in year $t$ as a reduction of the firm workforce by at least 60 percent between December $31^{\text {st }}$ of year $t-1$ and December $31^{\text {st }}$ of year $t$. We override the downsizing indicator if at least 60 percent of the workforce work together in year $t$ (interpreted as a reorganization event) or if the workforce moved back above the 40 percent mark in year $t+1$.
} 
Table 1. Bankruptcy and downsizing among immigrant and native workers

\begin{tabular}{|c|c|c|c|c|c|c|}
\hline & $\begin{array}{c}\text { LDC } \\
\text { immigrant } \\
(1)\end{array}$ & $\begin{array}{c}\text { Men } \\
\text { EEA } \\
\text { immigrant } \\
(2) \\
\end{array}$ & $\begin{array}{c}\text { Native } \\
\text { (3) }\end{array}$ & $\begin{array}{c}\text { LDC } \\
\text { immigrant } \\
(4) \\
\end{array}$ & $\begin{array}{c}\text { Women } \\
\text { EEA } \\
\text { immigrant } \\
(5) \\
\end{array}$ & $\begin{array}{c}\text { Native } \\
(6)\end{array}$ \\
\hline Firm bankrupt yrs 1-3 (\%) & 2.9 & 3.1 & 1.9 & 2.4 & 1.7 & 1.5 \\
\hline Firm downsizes yrs 1-3 (\%) & 10.9 & 8.7 & 7.7 & 11.4 & 9.3 & 8.7 \\
\hline Observations & 225108 & 236755 & 820901 & 82734 & 114003 & 459443 \\
\hline \multicolumn{7}{|c|}{$\begin{array}{l}\text { Note: Samples consist of private sector employees as of Dec } 31 \text { in the observation year (full population of the tu } \\
\text { immigrant groups and } 10 \text { percent extract of natives) and are restricted to those aged } 25-55 \text {. The bankruptcy } \\
\text { variable indicates that the firm closed down with a subsequent bankruptcy filing, and the downsizing variable } \\
\text { indicates that the firm reduced its staff by at least } 60 \text { percent (but did not go bankrupt) in one of the next three } \\
\text { years. }\end{array}$} \\
\hline
\end{tabular}

The table reveals that native men employed in the private sector have a 7.7 percent chance of being exposed to a major downsizing and a 1.9 percent chance of being exposed to a bankruptcy over the next three years (provided they stay with the firm until the shock hits). An LDC immigrant, on the other hand, is considerably more exposed to displacement with a 10.9 percent probability of the firm downsizing and a 2.9 percent probability of being laid off due to bankruptcy. Hence, both events are approximately 50 percent more likely for LDC immigrants than for natives. Similar patterns of overexposure are present for female LDC immigrants, somewhat higher for firm bankruptcy (60 percent) and somewhat lower for firm downsizing (30 percent). EEA immigrants also appear to be overexposed to downsizing events, particularly men.

In Table 2, we investigate whether differential exposures to adverse employment shocks can be explained by differences in the type of industries that immigrants and natives work in and/or by different individual characteristics. To do this, we estimate linear probability models where the outcome of interest is an indicator for whether or not the firm in which a person is employed will undergo a major downsizing or closure event during the next three calendar years.

As shown in columns (1) and (4), without any control variables LDC immigrant men (women) have a 4.1 (3.5) percentage points higher probability of being exposed to a downsizing or closure event than natives, whereas EEA immigrant men (women) have 2.2 (0.7) percentage points higher probability of exposure. Controlling for industry (with 87 dummy variables) and calendar year reduces these 
Table 2. Exposure to bankruptcy or downsizing; regression analysis

\begin{tabular}{|c|c|c|c|c|c|c|}
\hline & (1) & $\begin{array}{c}\text { Men } \\
(2)\end{array}$ & (3) & (4) & $\begin{array}{c}\text { Women } \\
(5)\end{array}$ & (6) \\
\hline LDC immigrant & $\begin{array}{c}0.041^{* * *} \\
(0.001)\end{array}$ & $\begin{array}{c}0.035^{* * *} \\
(0.001)\end{array}$ & $\begin{array}{c}0.013^{* * *} \\
(0.001)\end{array}$ & $\begin{array}{c}0.035^{* * *} \\
(0.002)\end{array}$ & $\begin{array}{c}0.035^{* * *} \\
(0.002)\end{array}$ & $\begin{array}{c}0.019 * * * \\
(0.002)\end{array}$ \\
\hline EEA immigrant & $\begin{array}{c}0.022 * * * \\
(0.001)\end{array}$ & $\begin{array}{c}0.020 * * * \\
(0.001)\end{array}$ & $\begin{array}{c}0.003^{* * *} \\
(0.001)\end{array}$ & $\begin{array}{c}0.007^{* * *} \\
(0.001)\end{array}$ & $\begin{array}{c}0.011 * * * \\
(0.001)\end{array}$ & $\begin{array}{l}0.003^{*} \\
(0.002)\end{array}$ \\
\hline Constant & $\begin{array}{c}0.096 * * * \\
(0.001)\end{array}$ & & & $\begin{array}{c}0.102 * * * \\
(0.001)\end{array}$ & & \\
\hline Controls & & $\begin{array}{l}\text { Year and } \\
\text { industry }\end{array}$ & $\begin{array}{c}\text { Add age, } \\
\text { experience, } \\
\text { tenure and } \\
\text { schooling; } \\
\text { county, firm } \\
\text { size, } \\
\text { proprietor, } \\
\text { immigrant } \\
\text { and foreign } \\
\text { ownership }\end{array}$ & & $\begin{array}{c}\text { Year and } \\
\text { industry }\end{array}$ & $\begin{array}{c}\text { Add age, } \\
\text { experience, } \\
\text { tenure and } \\
\text { schooling; } \\
\text { county, firm } \\
\text { size, } \\
\text { proprietor, } \\
\text { immigrant } \\
\text { and foreign } \\
\text { ownership }\end{array}$ \\
\hline Observations & & 1282764 & & & 666180 & \\
\hline
\end{tabular}

$* * * / * * / *$ Statistically significant at $1 / 5 / 10$ percent level.

Note: Standard errors, clustered within individuals, are shown in parentheses. The dependent variable is an indicator for whether or not the firm goes bankrupt or downsizes by at least 60 percent over the next three years. Samples consist of private-sector employees as of Dec 31 and age 25-55 in the observation year (full population of the two immigrant groups and 10 percent extract of natives). Specifications in cols (2) and (5) control for year (15 indicators) and 2-digit industry (87 indicators). Specifications in cols (3) and (6) add age and its square, actual experience and its square, tenure and its square, 7 indicators for educational attainment, 19 counties of residence, In(firm size), and indicators for sole proprietorship, immigrant owner, and foreign ownership.

differences somewhat, suggesting that immigrants indeed are overrepresented in risky industries; see columns (2) and (5). Yet, large and statistically significant differences remain. Accounting for differences in individual human capital variables, such as educational attainment, age, work experience (in Norway), and tenure reduces the immigrant-native differentials further, indicating that LDC immigrants to some extent are sorted into precarious firms due to their lower levels of human capital and work experience. Regardless of the underlying sorting mechanism, the fact that immigrants are considerably overrepresented in declining and dying firms is bound to be one ingredient in the overall explanation for their poor overall labor market performance. 


\section{Effects of adverse employment shocks}

We next turn to the impacts of exposure to a major downsizing event or firm closure. To begin, we first look at descriptive statistics for the full sample of wage earners examined in the previous section. Worker outcomes at the end of the three-year period, with and without an intermittent employer bankruptcy or downsizing event, are shown in Table 3. For all groups considered, we find that those who worked in firms that closed down due to bankruptcy over the next three years had much lower employment rates at the end of this period when compared to workers in stable firms. The bankruptcy employment differential for native workers is close to 10 percentage points and the workers in downsizing firms experienced five percentage points lower employment compared to workers in stable firms. While these differentials are similar for natives and EEA immigrants, Table 3 hints that the consequences of job displacement may be more severe for LDC immigrants. It is clear, however, that the immigrant-native employment differentials are far from fully explained by differences in firm employment shocks. Notably, the employment rates three year after the base year for LDC immigrants working in stable firms are similar to those of natives working in firms about to go bankrupt.

Job loss may trigger migration abroad as well as mobility within Norway to another labor market region. As in Bijwaard et al. (2014), we find a correlation between individual non-employment and outmigration. The pattern is especially evident for immigrant men. As Table 3 shows, the outmigration rate among male immigrants employed in firms that go bankrupt is 50 percent higher than that among immigrant men employed in firms with a steady workforce over the 3-year period. This pattern holds for both LDC and EEA men, despite the fact that immigrant men from rich countries have five times the outmigration rate of those from poor countries. For women, the difference in outmigration between rich and poor country immigrants is even larger, while the interaction with job displacement is less clear as the outmigration rate of female LDC immigrants working in bankruptcy firms is comparable to that in stable firms.

Internal mobility rates, on the other hand, are consistently higher for those exposed to bankruptcy, and employees are also more likely to move to another labor market region in Norway if the firm reduces its workforce. ${ }^{4}$ Among immigrants, internal mobility is generally higher for men than for women, while the gender difference is very small for natives. There are also indications in Table 3 that internal mobility of immigrants is more sensitive to job displacements, when compared to natives.

\footnotetext{
${ }^{4}$ Labor market regions in Norway are defined on the basis of travel-to-work areas. We use a partition with 46 such regions, with approximately 110,000 inhabitants on average (see Bhuller, 2009).
} 
Table 3. Outmigration, internal mobility and employment; by immigrant background and firm employment shock

\begin{tabular}{|c|c|c|c|c|c|c|}
\hline & $\begin{array}{c}\text { LDC imm } \\
(1)\end{array}$ & $\begin{array}{l}\text { Men } \\
\text { EEA imm } \\
(2)\end{array}$ & $\begin{array}{c}\text { Native } \\
\text { (3) }\end{array}$ & $\begin{array}{l}\text { LDC imm } \\
(4)\end{array}$ & $\begin{array}{l}\text { Women } \\
\text { EEA imm } \\
(5)\end{array}$ & $\begin{array}{c}\text { Native } \\
(6)\end{array}$ \\
\hline \multicolumn{7}{|c|}{ Outmigrated by end of yr 3 (\%) } \\
\hline Firm bankrupt yrs 1-3 & 2.5 & 13.1 & 0.4 & 1.1 & 13.5 & 0.4 \\
\hline Firm downsizes yrs 1-3 & 2.4 & 12.9 & 0.5 & 1.5 & 10.8 & 0.3 \\
\hline Firm stable & 1.6 & 9.1 & 0.3 & 1.0 & 8.5 & 0.3 \\
\hline \multicolumn{7}{|c|}{ Internal mobility by end of yr 3 (\%) } \\
\hline Firm bankrupt yrs 1-3 & 10.8 & 17.5 & 6.1 & 9.4 & 12.7 & 6.2 \\
\hline Firm downsizes yrs 1-3 & 8.9 & 13.9 & 5.6 & 5.9 & 10.3 & 5.3 \\
\hline Firm stable & 6.6 & 11.5 & 4.4 & 4.8 & 8.2 & 4.2 \\
\hline \multicolumn{7}{|l|}{ Employed yr 3 (\%) } \\
\hline Firm bankrupt yrs 1-3 & 78.2 & 87.2 & 89.7 & 66.9 & 83.2 & 84.4 \\
\hline Firm downsizes yrs 1-3 & 82.2 & 91.0 & 94.0 & 72.4 & 88.7 & 89.6 \\
\hline Firm stable & 89.4 & 96.0 & 97.4 & 84.3 & 94.3 & 94.7 \\
\hline Observations & 224562 & 235912 & 817774 & 82631 & 123783 & 458391 \\
\hline \multicolumn{7}{|c|}{$\begin{array}{l}\text { Note: Sample consists of private-sector employees as of Dec } 31 \text { and age } 25-55 \text { in the observation base year (full } \\
\text { population of the two immigrant groups and } 10 \text { percent extract of natives). Internal mobility indicates move } \\
\text { between two of } 46 \text { local labor markets. Internal mobility and employment rates are conditional on continued } \\
\text { residency at the end of vear } 3\end{array}$} \\
\hline
\end{tabular}

The evidence in Table 3 strongly suggests that employer events that trigger job displacement have important implications for future employment and mobility of affected workers. These empirical patterns do not necessarily reflect causal mechanisms, however. First, there is a potential problem of reverse causality, in the sense that it might be low worker productivity (and, hence, low employability) that causes the downsizing and firm closure, and not vice versa. Second, it is probable that firms that are going to downsize or close down in the near future also have had problems in the past, such that a sorting process among employees has already taken place before our baseline, for example such that only workers with poor outside options remain in the firm. And third, even in the absence of past downsizings, it is possible that particularly feeble and unprofitable firms have disproportionally recruited workers with poor employment prospects. 


\section{Restricting the sample to ensure exogeneity}

In order to overcome such endogeneity problems and identify the causal impacts of being exposed to a downsizing or closure event, we impose a number of restrictions on our analysis sample. First, to avoid reverse causality, we focus on firms of some size (at least 10 employees in the base year). Second, in order to facilitate a clean comparison of exposed and non-exposed workers, we design the data such that none of the included firms have undergone downsizing/closure events in the two-year period prior to our baseline. More specifically, our analysis data are constructed as follows: For each base year $t_{0}=1994, \ldots, 2010$, we identify private sector workers in firms that have not been exposed to any major downsizings in either of the years $t_{0}-2, t_{0}-1, t_{0}$, or $t_{0}+1$. We also require that they have worked in that same firm for at least one year and that they have been employed the last three calendar years without any spells on unemployment insurance. Then, in year $t_{0}+2$, some of the firms are exposed to a major downsizing or closure event, and some are not. Assuming that a forthcoming closure/downsizing may cause displacements and voluntary quits prior to its actual occurrence, the purpose of our analysis is to study how these events affect employment and earnings patterns from year $t_{0}+1$ onwards.

These sample restrictions - which arguably are necessary in order to ensure that we can interpret the downsizing/closure events as exogenous with respect to worker characteristics - imply that we lose a large number of observations; compare the observation counts reported in Tables 3 and 4 . For the two immigrant groups, we lose as many as two thirds of the observations, whereas we lose approximately half of the observations for natives. This obviously implies that the worker groups used to identify the effects of negative employment shocks are not necessarily representative for the three worker groups as a whole. As reported in Table 4, the sample restrictions also imply that all three groups are far less exposed to firm shocks than the overall work force as shown in Table 1. The differences between the three demographic groups have also become considerably smaller. Yet, the immigrant overexposure to bankruptcy events remains large-for men about 40 percent for both immigrant groups, and for women about 70 percent for LDC immigrants (and no overexposure for female EEA immigrants).

The three demographic groups also differ in terms of observed characteristics. LDC immigrants are younger and have less work experience, tenure and education than immigrants from the EEA. As we only account for post-migration labor market experience, both immigrant groups have worked less and have shorter tenure with the firm than natives. 
Table 4. Descriptive statistics, restricted samples

\begin{tabular}{|c|c|c|c|c|c|c|}
\hline & $\begin{array}{l}\text { LDC imm } \\
\text { (1) }\end{array}$ & $\begin{array}{c}\text { Men } \\
\text { EEA imm } \\
(2) \\
\end{array}$ & $\begin{array}{c}\text { Native } \\
(3)\end{array}$ & $\begin{array}{c}\text { LDC imm } \\
(4)\end{array}$ & $\begin{array}{c}\text { Women } \\
\text { EEA imm } \\
(5)\end{array}$ & $\begin{array}{c}\text { Native } \\
(6)\end{array}$ \\
\hline Firm bankrupt yr $t_{0}+2(\%)$ & 0.53 & 0.52 & 0.37 & 0.47 & 0.27 & 0.27 \\
\hline Firm downsizes $t_{0}+2(\%)$ & 2.29 & 2.10 & 2.14 & 2.60 & 2.30 & 2.22 \\
\hline Age $\mathrm{yr} t_{0}$ & 38.9 & 41.9 & 40.7 & 38.2 & 40.8 & 40.7 \\
\hline Actual experience yr $t_{0}$ & 11.9 & 13.9 & 20.6 & 9.1 & 13.3 & 18.3 \\
\hline Tenure yr $t_{0}$ & 5.8 & 6.3 & 8.1 & 4.5 & 5.6 & 6.6 \\
\hline Low education (\%) & 42.7 & 27.4 & 30.9 & 46.6 & 23.1 & 41.7 \\
\hline Medium education (\%) & 35.9 & 30.6 & 44.1 & 32.4 & 26.8 & 31.9 \\
\hline High education (\%) & 21.3 & 42.0 & 29.9 & 20.9 & 50.0 & 26.3 \\
\hline Observations & 82467 & 89569 & 435272 & 26144 & 44304 & 204344 \\
\hline \multicolumn{7}{|c|}{$\begin{array}{l}\text { Note: Samples consist of private-sector workers age } 25-55 \text { with more than one year of tenure in a firm with at least } \\
10 \text { employees on Dec } 31 \text { of the base year, which is two years prior to any bankruptcy/downsizing event. Samples } \\
\text { are further restricted to those with employment each year and not receiving benefits nor working in a firm that } \\
\text { downsized during the } 3 \text {-year period ending with the base year. The bankruptcy variable indicates that the firm filed } \\
\text { for bankruptcy and the downsizing variable that the firm reduced its staff by at least } 60 \text { percent (but did not go } \\
\text { bankrupt) during the calendar year two years after the base year. The education classifications are less than high- } \\
\text { school (low); completed high-school but no college degree (medium); and college degree or higher (high). }\end{array}$} \\
\hline
\end{tabular}

The impacts of downsizing or bankruptcy events on future labor market outcomes are illustrated in Figures 3 through 5, separately for natives and the two immigrant groups and by gender. The figures reveal how three key outcomes evolve over time for exposed and non-exposed workers, conditional on continued residency in Norway, up to six years after the base year. In the figures, year zero still denotes the base year (the last of three years with conditioned employment), whereas year 2 (marked with a vertical line) is the year when the downsizing or closure event potentially occurs.

First, Figure 3 displays the pattern of registered unemployment incidence over time and across groups. Unemployment is here defined as being registered as an unemployed job seeker at an employment office by the end of any month during the calendar year. Not surprisingly, workers exposed to exogenous events of bankruptcy have much higher unemployment incidence than workers in stable firms, and this applies to immigrants as well as natives. Employees in firms with a major downsizing are also more prone to unemployment. Since not all employees are laid off, the incidence is much lower than for bankruptcies. The higher incidence among LDC immigrants may in part reflect that they have less seniority within the firm, and therefore more likely directly affected by the downsizing event. 


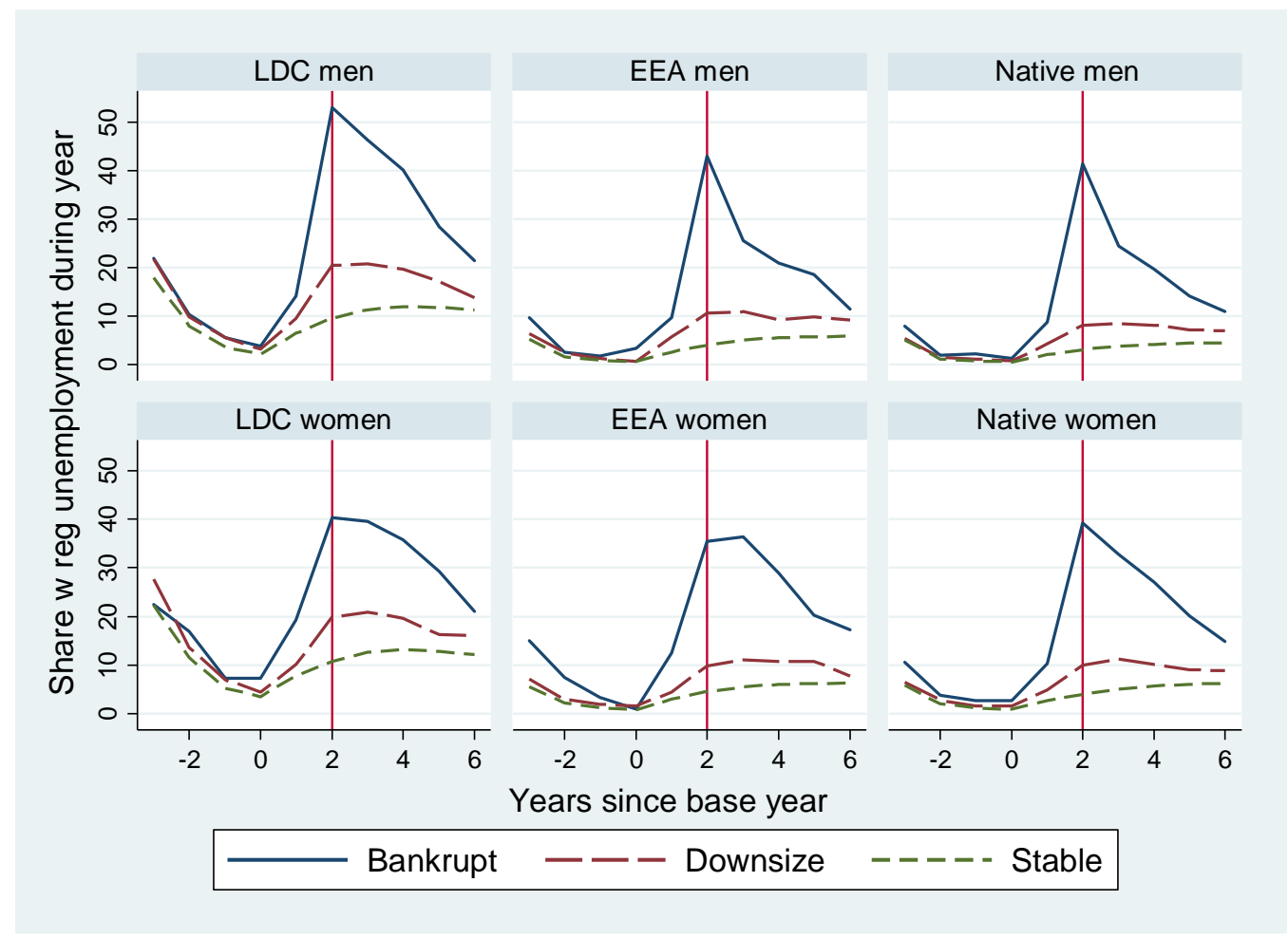

Figure 3. Yearly registered unemployment by immigrant background and firm shock

An important reason for discussing Figure 3 is that the figure entries provide insights into the relationship between job loss and unemployment incidence. By definition, a closure due to bankruptcy is known to imply that all employees lose their job. The fact that "only" 40 percent of native workers in this category register as unemployed during the year of firm closure, shows that a slight majority of displaced workers either are able to find new employment in time to avoid an intermittent unemployment spell, or pull out of the labor market. For LDC immigrants, the fraction registering as unemployed is somewhat higher (about 50 percent), indicating that these workers to a lesser extent than natives find a new job in time to circumvent a spell of unemployment. Based on these numbers, it is possible to use the observed rates of registered unemployment for workers in other (non-closing) firms to back out the approximate fraction of job loss in these firms-a point to which we return below.

Figures 4 and 5 display patterns of employment and labor earnings relative to the base year for workers in closing, downsizing and stable firms. It is evident that workers employed in firms that go bankrupt perform much worse over time than workers in stable firms. The effects appear to be long lasting, 


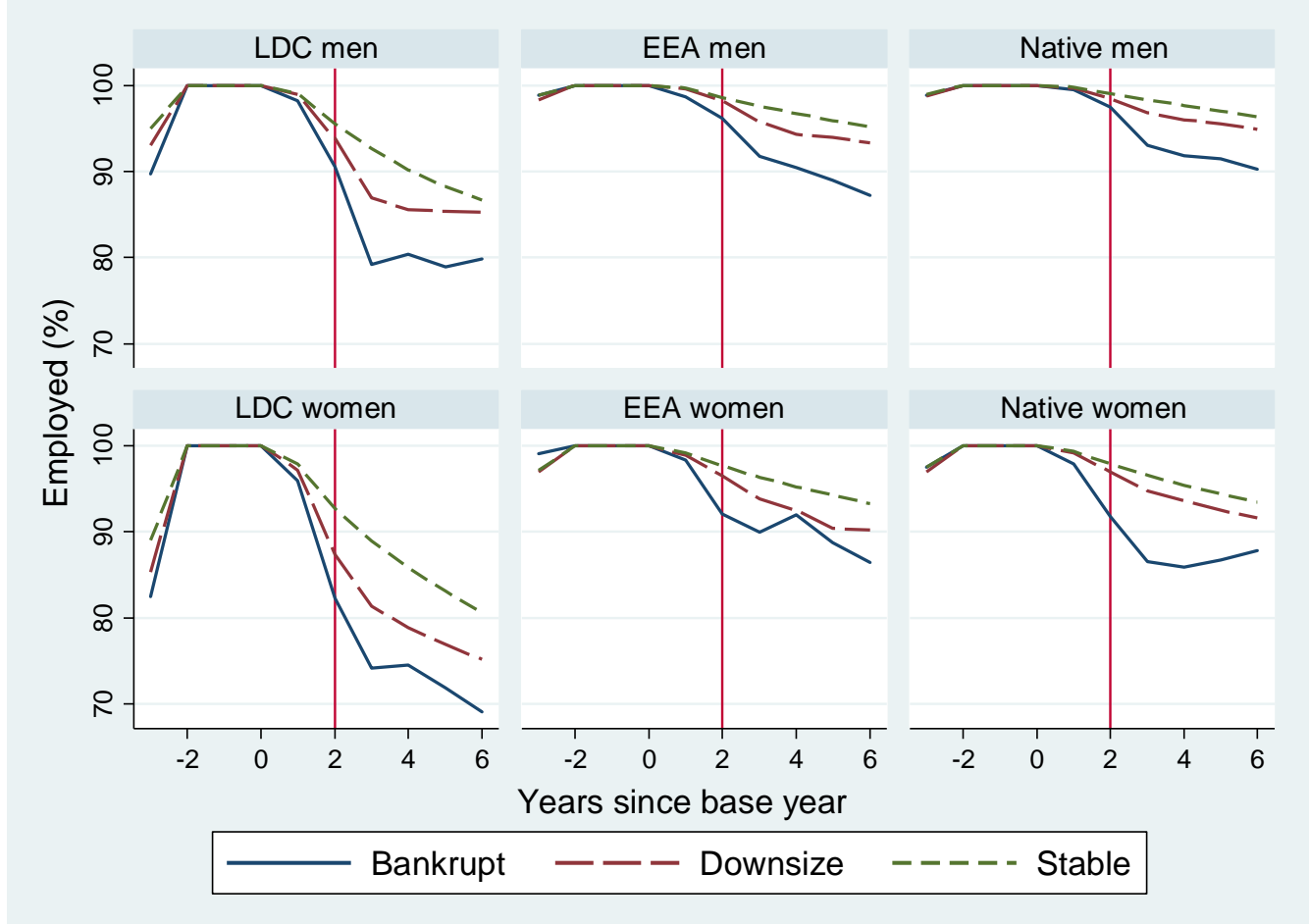

Figure 4. Employment by immigrant background and firm shock

although there are signs of convergence for most groups four years after the closure event. A negative employment effect is indicated for all groups, regardless of immigrant background and gender. However, the immediate negative employment shock appears to be much larger for LDC immigrants than for natives and EEA immigrants. The pattern is similar for the responses to major downsizings, although the magnitudes of the effects, as expected, are much smaller than for bankruptcies.

As was the case for employment, Figure 5 suggests considerable earnings losses in the years following adverse employment shocks. Since we have not conditioned on continued employment in these graphs, most of the earnings losses mirror the employment decline described above. For both EEA immigrants and natives, earnings losses seem to be moderate, but persistent. For men in closing firms, there remains a non-trivial earnings loss four years after the bankruptcy (and six years after the base year). For male LDC immigrants, on the other hand, there is a much larger negative short-term earnings drop associated with the bankruptcy, but the effect appears to be almost washed out after four years. It is notable, however, that none of the LDC immigrant groups experience any earnings growth over time, 


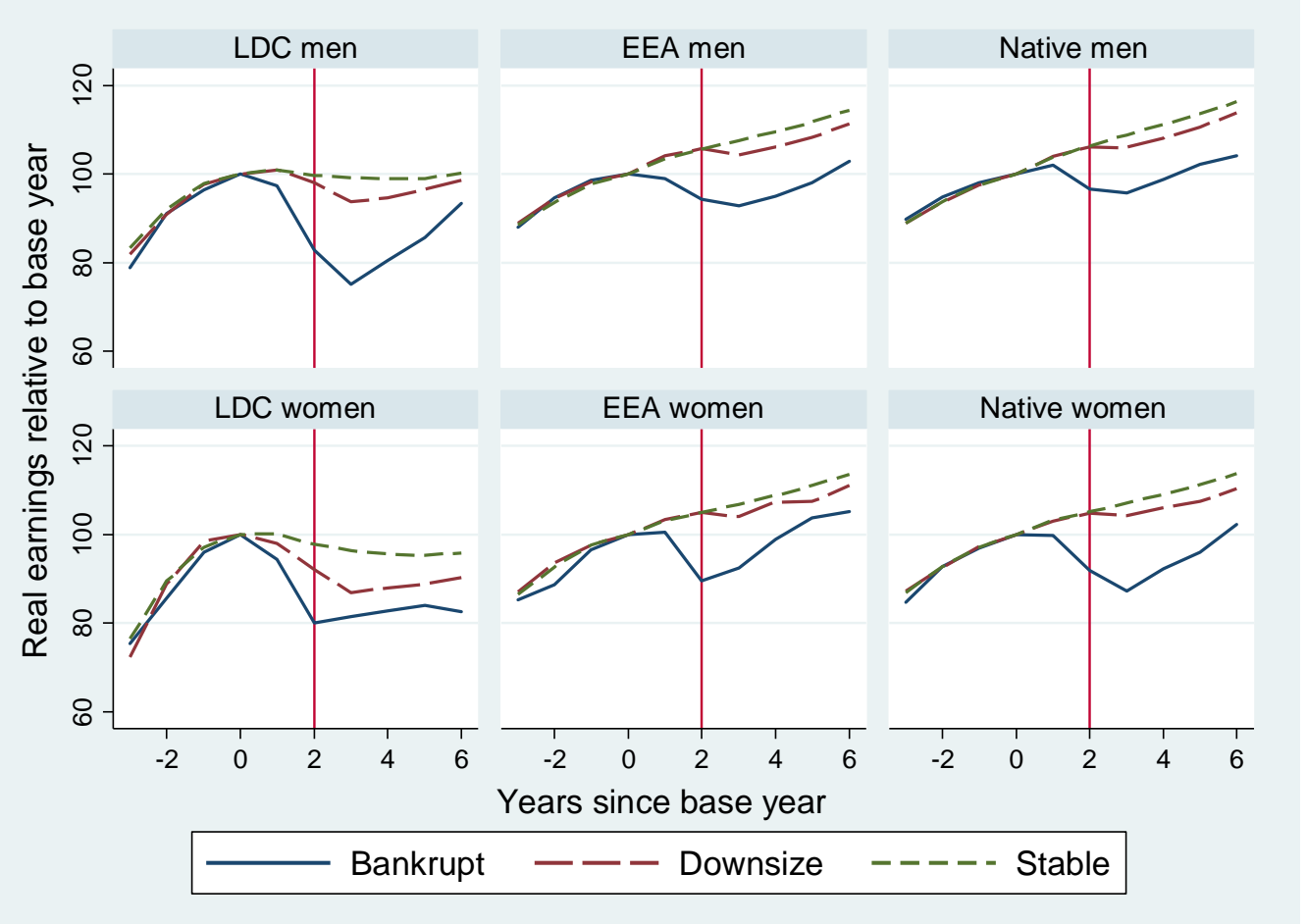

Figure 5. Earnings relative to base year by immigrant background and firm shock

Note: Earnings are normalized to 100 in the base year, $t_{0}$. In year $t_{0}-3$ and years $t_{0}+1$ to $t_{0}+6$, average earnings are not conditional on employment and will include some individuals with zero earnings.

irrespective of initial employment in stable, downsizing, or closing firms. Hence, any convergence in earnings profiles by type of firm shock among LDC immigrants is not the result of bankruptcy-exposed workers picking up particularly fast, but rather the failure of workers in stable firms to improve their earnings over time. A point to note here is that although those in stable firms by construction did not experience any major employment shock by year 2, some will have experienced such shocks later on. Based on the descriptive statistics in Table 4, we can assume that this happens more frequently for the employers of LDC immigrants. This, along with greater exposure to moderate downsizings, may explain the steeper employment decline in the group of LDC immigrants in "stable" firms revealed by Figure 4.

\section{Regression analysis of employment and earnings outcomes}

We now turn to the regression analyses, where we seek to estimate the impacts of being exposed to a mass layoff. In these analyses, we control for potential confounders, i.e., variables that may be correlated with both the probability of being exposed to downsizing/closure events and future labor 
market performance. This includes all observed human capital variables as well as observed labor market performance prior to the base year.

Denoting the labor market outcome measured in a certain year (or a certain period) $t$ following the base year $t_{0}$ (e.g., $t=t_{0}+3$ ) of an individual $i$ who in the base year worked in industry $j$ as $y_{i j t}$, our regression equations take the form:

$$
y_{i j t}=\mathbf{X}_{\mathrm{it}}^{\prime} \boldsymbol{\beta}+\mathbf{D}_{\mathbf{i t}}^{\prime} \gamma+\mathbf{1}^{\prime} \mathbf{M}_{\mathbf{i}}\left(\mathbf{X}_{\mathrm{it}}^{\prime} \boldsymbol{\beta}_{\mathbf{I}}+\mathbf{D}_{\mathrm{it}}^{\prime} \gamma_{\mathbf{I}}\right)+\mu_{j}+\tau_{t}+\varepsilon_{i j t},
$$

where the vector $\mathbf{M}$ contains indicators for the two immigrant groups (LDC or EEA), the vector $\mathbf{D}$ indicators for the two types of downsizing and closure events, $\mu_{j}$ is an industry fixed effect, $\tau_{t}$ a year fixed effect, $\mathbf{X}$ a vector of individual covariates, and $\varepsilon_{i j t}$ is a residual. The individual covariates include educational attainment (eight categories), age, work experience, and tenure (the latter three variables in the form of quadratic polynomials). In earnings regressions, we include log base-year earnings as an additional covariate.

Table 5 presents estimation results for three different employment outcomes, separately for men and women. The first outcome is a dichotomous variable indicating employment in the year after the potential closure/downsizing event (i.e., in year $t_{0}+3$ ). The other two outcomes measure the average employment rate over three and five-year periods. The three-year outcome extends the post-closure period, while the five-year period starts one year prior to the potential downsizing/closure event and thus incorporates "anticipation" effects of a forthcoming employment shock as well as more gradual downsizing processes prior to the major downsizing or closure.

In any case, our main interest lies in the coefficients $\left(\gamma, \gamma_{I}\right)$, i.e., the "main" (native) effects of the year $t_{0}+2$ downsizing/closure events and whether there are differential effects for immigrants, reflected in the coefficients of interaction terms. Since the empirical model includes the full set of interactions between immigrant background and individual characteristics, there is no single immigrant-native differential. 
Table 5. Employment following bankruptcy or downsizing

\begin{tabular}{|c|c|c|c|c|c|c|}
\hline & $\begin{array}{c}\text { Year } 3 \\
(1) \\
\end{array}$ & $\begin{array}{c}\text { Men } \\
3 \text { year period } \\
\text { (yrs 3-5) } \\
(2) \\
\end{array}$ & $\begin{array}{c}5 \text { year period } \\
\text { (yrs 1-5) } \\
(3) \\
\end{array}$ & $\begin{array}{c}\text { Year } 3 \\
(4) \\
\end{array}$ & $\begin{array}{c}\text { Women } \\
3 \text { year period } \\
\text { (yrs 3-5) } \\
(5)\end{array}$ & $\begin{array}{c}5 \text { year period } \\
\text { (yrs 1-5) } \\
(6)\end{array}$ \\
\hline \multicolumn{7}{|l|}{ A. Sample means } \\
\hline LDC immigrants & 0.925 & 0.904 & 0.931 & 0.887 & 0.857 & 0.893 \\
\hline EEA immigrants & 0.976 & 0.967 & 0.977 & 0.963 & 0.952 & 0.965 \\
\hline Natives & 0.983 & 0.977 & 0.984 & 0.965 & 0.955 & 0.967 \\
\hline \multicolumn{7}{|l|}{ B. Regression } \\
\hline Bankrupt & $\begin{array}{c}-0.046 * * * \\
(0.006)\end{array}$ & $\begin{array}{c}-0.052^{* * *} \\
(0.006)\end{array}$ & $\begin{array}{c}-0.033^{* * *} \\
(0.004)\end{array}$ & $\begin{array}{c}-0.088^{* * *} \\
(0.014)\end{array}$ & $\begin{array}{c}-0.079 * * * \\
(0.013)\end{array}$ & $\begin{array}{c}-0.062 * * * \\
(0.010)\end{array}$ \\
\hline LDC*bankrupt & $\begin{array}{c}-0.080 * * * \\
(0.020)\end{array}$ & $\begin{array}{c}-0.057^{* * *} \\
(0.019)\end{array}$ & $\begin{array}{c}-0.041 * * * \\
(0.013)\end{array}$ & $\begin{array}{l}-0.047 \\
(0.042)\end{array}$ & $\begin{array}{c}-0.033 \\
(0.042)\end{array}$ & $\begin{array}{l}-0.026 \\
(0.031)\end{array}$ \\
\hline EEA*bankrupt & $\begin{array}{c}-0.004 \\
(0.015)\end{array}$ & $\begin{array}{c}-0.008 \\
(0.015)\end{array}$ & $\begin{array}{l}-0.011 \\
(0.010)\end{array}$ & $\begin{array}{c}0.039 \\
(0.032)\end{array}$ & $\begin{array}{c}0.041 \\
(0.028)\end{array}$ & $\begin{array}{c}0.032 \\
(0.021)\end{array}$ \\
\hline Downsize & $\begin{array}{c}-0.015^{* * *} \\
(0.002)\end{array}$ & $\begin{array}{c}-0.016 * * * \\
(0.002)\end{array}$ & $\begin{array}{c}-0.011^{* * *} \\
(0.001)\end{array}$ & $\begin{array}{c}-0.014 * * * \\
(0.003)\end{array}$ & $\begin{array}{c}-0.014 * * * \\
(0.003)\end{array}$ & $\begin{array}{c}-0.009 * * * \\
(0.002)\end{array}$ \\
\hline LDC*downsize & $\begin{array}{c}-0.037 * * * \\
(0.008)\end{array}$ & $\begin{array}{c}-0.023^{* * *} \\
(0.008)\end{array}$ & $\begin{array}{c}-0.015^{* * *} \\
(0.005)\end{array}$ & $\begin{array}{c}-0.055^{* * *} \\
(0.015)\end{array}$ & $\begin{array}{c}-0.049 * * * \\
(0.015)\end{array}$ & $\begin{array}{c}-0.038^{* * *} \\
(0.011)\end{array}$ \\
\hline EEA*downsize & $\begin{array}{l}-0.002 \\
(0.005)\end{array}$ & $\begin{array}{c}-0.004 \\
(0.005)\end{array}$ & $\begin{array}{l}-0.002 \\
(0.004)\end{array}$ & $\begin{array}{l}-0.005 \\
(0.008)\end{array}$ & $\begin{array}{c}-0.012 \\
(0.009)\end{array}$ & $\begin{array}{c}-0.008 \\
(0.006)\end{array}$ \\
\hline Observations & 598654 & 471746 & 471746 & 271131 & 214840 & 214840 \\
\hline
\end{tabular}

$* * * / * * / *$ Statistically significant at $1 / 5 / 10$ percent level.

Note: Standard errors, clustered within individuals, are shown in parentheses. The dependent variable is an indicator for employment (cols 1 and 4), and the (average) employment rate over the three (cols 2 and 5) or five year period (cols 3 and 6). Samples in cols (1) and (4) consist of those in the country on Dec 31 three years after the base year and cols (2), (3), (5) and (6) five years after the base year, in addition to the sample restrictions detailed in note to table 4. All specifications control for year and 2-digit industry, as well as age and its square, actual experience and its square, tenure and its square, and seven indicators for educational attainment, with all individual characteristics interacted with indicators for each of the two immigrant categories.

In order to facilitate interpretation of the estimated effects, we first report average outcomes for all three demographic groups in panel A of Table 5. As the panel shows, employment rates are considerably lower for LDC immigrants than for natives and European immigrants. For example, three years after the base year, the LDC immigrant employment gap relative to natives is 5.8 percentage points for males and 7.8 points for women. We also see that employment rates are permanently lower as the five years average gap is 5.3 for LDC men and 7.4 for LDC women. 
The estimated effects of a bankruptcy, or major downsizing, are given by the regression coefficients in Table 5, Panel B. We focus primarily on the impact of a closure with bankruptcy. Although bankruptcies are rare, they provide the best case for displacements that are uncorrelated with worker characteristics. These events also constitute the cleanest case of mass layoffs that can be identified from our data, with a minimum of measurement error. Hence, by tracking outcomes among employees during years following their employer bankruptcy, we get as close as possible to identify the causal effect of a job loss. First, a bankruptcy has a negative short run effect on employment of both men and women (columns 1 and 4). For native women, employment drops by 8.8 percentage points the year following firm closure, while the effect is 4.7 percentage points for men. These estimates are slightly larger than those of displaced male manufacturing employees found by Huttunen et al. (2011). The consequences of job loss are even more severe for LDC immigrants, for whom the bankruptcy effect is to reduce employment by approximately 13 percentage points for men (-0.046-0.080=-0.126). For female immigrants, we do not find statistically significant effects of bankruptcy beyond that of natives, although the point estimates indicate similar effects for female and male LDC immigrants. Note that the estimates are based on a linear probability model and the additional impact of firm bankruptcy for LDC immigrants is in terms of absolute employment differentials.

Downsizing also affects employment in the short run. The effects are less severe than those of bankruptcy, as expected. The effects of downsizing events can be interpreted as "intention to treat" effects since up to 40 percent of the workforce remains with the firm. The employment effect for natives is about 1.5 percentage points, for both men and women. Again, the negative employment effects are considerably larger for LDC immigrants.

Moving on to the 3-year and 5-year averages, we first note that the sample means reveal that the average employment differential for LDC male immigrants, relative to natives, is -0.073 over the 3 -year period after a possible closure and -0.047 for the five-year period where we also include the year before and the year of the closure. For LDC women, the employment gap relative to natives is persistently higher, at around 9 percentage points. EEA immigrants are just slightly less employed than natives. Turning to the regression results in panel $\mathrm{B}$, with all available control variables included in the specification, we find that a bankruptcy reduces the subsequent average 3-year employment rate of native men by 5.2 percentage points (column 2 ) and 3.3 points annually over the 5 -year period (column 3). For male LDC immigrants the effects are roughly twice as large with estimates of $-0.109(=-0.052-$ $0.057)$ for the 3 -year average and $-0.074(=-0.033-0.041)$ for the 5 -year average. For native women, 
employment effects are estimated to -0.079 ( 3 years, column 5 ) and -0.062 (5 years, column 6 ). Again, the estimates are larger for LDC immigrants, although the interaction terms are not statistically significant.

Even the effects of a major downsizing are long lasting. For native men, the effects are -0.016 and 0.011 on the average 3-year and 5-year employment rates, respectively. Like for bankruptcy, the effects are twice as large for male LDC immigrants. Downsizing seems to have particularly severe effects on LDC women, and the negative employment effects are four times those of native women. The larger effects of downsizing for LDC immigrants may in part reflect that their greater likelihood of layoff during an organizational restructuring process. Unlike bankruptcy, downsizing identifies an intention-to-treat effect. The selection of workers to be laid off will typically be determined by last-in-first-out (LIFO) practices, which means that LDC immigrants with shorter tenure are more directly affected by the adverse employment shock. While the downsizing/closure effects on employment for LDC immigrants are significantly larger than for natives, there is no evidences of additional effects for EEA immigrants.

Figure 4 indicated that the labor earnings loss could be substantial, and in Table 6 we report the estimated effects of displacement on log earnings. Again we conduct the analysis separately for the first year after the potential employment shock and for cumulative earnings over the 3-year period following any bankruptcy/downsizing as well as the 5-year period including the year before and the year of the firm employment shock. Earnings are inflated to 2012 NOK for all years. Given the log earnings specification, observations with zero earnings are dropped. While this reduces the number of observations somewhat when the outcome variable is earnings in a single year, it has negligible impacts on the number of observations for the cumulative outcomes; compare the observation counts in Tables 5 and 6.

As in the discussion of employment effects, we focus on the coefficients of bankruptcy and first discuss the impacts on short-run earnings. For men in column (1) we see that bankruptcy implies a drop in earnings in the first post-closure year of $0.213 \log$ point for natives and $0.422(=0.213+0.209)$ log point for LDC immigrants. The extra effect for LDC immigrants is both substantively and statistically significant. The earnings loss among native women is even larger than that of native men, but the extra effect of bankruptcy for female LDC immigrants is smaller than that of men and not statistically significant. 
Table 6. Log earnings following bankruptcy or downsizing

\begin{tabular}{|c|c|c|c|c|c|c|}
\hline & $\begin{array}{c}\text { Year } 3 \\
(1) \\
\end{array}$ & $\begin{array}{c}\text { Men } \\
3 \text { year period } \\
\text { (yrs 3-5) } \\
(2) \\
\end{array}$ & $\begin{array}{c}5 \text { year period } \\
\text { (yrs 1-5) } \\
(3)\end{array}$ & $\begin{array}{c}\text { Year } 3 \\
(4) \\
\end{array}$ & $\begin{array}{c}\text { Women } \\
3 \text { year period } \\
\text { (yrs 3-5) } \\
(5)\end{array}$ & $\begin{array}{c}5 \text { year period } \\
\text { (yrs 1-5) } \\
(6)\end{array}$ \\
\hline \multicolumn{7}{|l|}{ A. Sample means } \\
\hline LDC immigrants & 12.753 & 13.789 & 14.387 & 12.437 & 13.442 & 14.068 \\
\hline EEA immigrants & 13.157 & 14.238 & 14.766 & 12.825 & 13.892 & 14.427 \\
\hline Natives & 13.112 & 14.200 & 14.716 & 12.718 & 13.789 & 14.323 \\
\hline \multicolumn{7}{|l|}{ B. Regression } \\
\hline Bankrupt & $\begin{array}{c}-0.213^{* * *} \\
(0.020)\end{array}$ & $\begin{array}{c}-0.212^{* * *} \\
(0.022)\end{array}$ & $\begin{array}{c}-0.124^{* * *} \\
(0.011)\end{array}$ & $\begin{array}{c}-0.326 * * * \\
(0.043)\end{array}$ & $\begin{array}{c}-0.244^{* * *} \\
(0.040)\end{array}$ & $\begin{array}{c}-0.184^{* * *} \\
(0.026)\end{array}$ \\
\hline LDC* bankrupt & $\begin{array}{c}-0.209 * * * \\
(0.058)\end{array}$ & $\begin{array}{l}-0.100 \\
(0.064)\end{array}$ & $\begin{array}{l}-0.050 \\
(0.033)\end{array}$ & $\begin{array}{l}-0.120 \\
(0.136)\end{array}$ & $\begin{array}{l}-0.150 \\
(0.175)\end{array}$ & $\begin{array}{c}0.000 \\
(0.069)\end{array}$ \\
\hline EEA*bankrupt & $\begin{array}{l}-0.010 \\
(0.045)\end{array}$ & $\begin{array}{l}-0.024 \\
(0.051)\end{array}$ & $\begin{array}{l}-0.043 \\
(0.030)\end{array}$ & $\begin{array}{c}0.096 \\
(0.106)\end{array}$ & $\begin{array}{c}0.109 \\
(0.093)\end{array}$ & $\begin{array}{c}0.074 \\
(0.053)\end{array}$ \\
\hline Downsize & $\begin{array}{c}-0.060 * * * \\
(0.010)\end{array}$ & $\begin{array}{c}-0.067^{* * *} \\
(0.007)\end{array}$ & $\begin{array}{c}-0.037^{* * *} \\
(0.004)\end{array}$ & $\begin{array}{c}-0.059 * * * \\
(0.010)\end{array}$ & $\begin{array}{c}-0.061 * * * \\
(0.011)\end{array}$ & $\begin{array}{c}-0.030 * * * \\
(0.006)\end{array}$ \\
\hline LDC*downsize & $\begin{array}{c}-0.102 * * * \\
(0.025)\end{array}$ & $\begin{array}{c}-0.058 * * \\
(0.028)\end{array}$ & $\begin{array}{c}-0.029 * \\
(0.015)\end{array}$ & $\begin{array}{c}-0.088^{*} \\
(0.047)\end{array}$ & $\begin{array}{l}-0.065 \\
(0.054)\end{array}$ & $\begin{array}{c}-0.104 * * * \\
(0.034)\end{array}$ \\
\hline EEA*downsize & $\begin{array}{c}0.007 \\
(0.015)\end{array}$ & $\begin{array}{c}0.008 \\
(0.017)\end{array}$ & $\begin{array}{l}-0.008 \\
(0.011)\end{array}$ & $\begin{array}{c}0.022 \\
(0.024)\end{array}$ & $\begin{array}{c}0.009 \\
(0.028)\end{array}$ & $\begin{array}{c}-0.011 \\
(0.017)\end{array}$ \\
\hline Observations & 592686 & 469277 & 471727 & 267318 & 213081 & 214822 \\
\hline
\end{tabular}

$* * * / * * *$ Statistically significant at $1 / 5 / 10$ percent level.

Note: Standard errors, clustered within individuals, are shown in parentheses. The dependent variable is log earnings from work (cols 1 and 4), and log cumulative earnings over the three (cols 2 and 5) or five year period (cols 3 and 6). Samples consist of those in the country on Dec 31 the last year of the observation period in addition to the sample restrictions detailed in note to Table 4. All specifications control for year and 2-digit industry, as well as age and its square, actual experience and its square, tenure and its square, seven indicators for educational attainment, and log cumulative earnings during the three-year period ending with the base year, with all individual characteristics interacted with indicators for each of the two immigrant categories.

The effects on cumulative earnings are of similar magnitude to the short run effects. Actually, for native men, we find that bankruptcy reduces 3 -year earnings by 0.212 log point, but that the 5 -year effect falls to 0.125 . This estimate is strikingly similar to the 12 percent earnings loss after six years among displaced US workers documented by Couch and Placzek (2010). For male LDC immigrants, the corresponding estimates imply reduced earnings of 0.312 and $0.174 \log$ point, although the interaction terms are not statistically significant. For native women, bankruptcy reduces 3 -year earnings by 0.244 log point and 5-year earnings by 0.185 log point. Again, we fail to uncover statistically significant 
interaction effects for female immigrants, although point estimates are sizeable for the 3-year earnings of LDC women.

As acknowledged above, even conditional on the extensive set of control variables, there is some risk that downsizing and closure events might be correlated with unobserved worker characteristics that also affect post-displacement outcomes. We fail, however, to uncover evidence that, in our restricted samples, workers exposed to bankruptcy or downsizing differ importantly from other workers in their industry. When we check for such bias by reestimating the model after removing all individual worker characteristics from the set of control variables, the effect estimates are very similar to those reported in Tables 5 and 6; see Table A-1 in the Appendix. Nevertheless, to account for time-invariant worker heterogeneity, we also consider earnings outcomes where we can control for worker fixed effects on the level of annual earnings. A straightforward measure of earnings growth is the change in log earnings between the base year and year $t_{0}+3$. Alternatively we also consider cumulative earnings in two equally long time periods, one for the three-year period starting the year after the potential employment shock $\left[t_{0}+3, t_{0}+5\right]$ (used as a dependent variable in Table 6 , cols 2 and 5 ) and one for the three-year period ending with the base year $\left[t_{0}-2, t_{0}\right]$. We then use the change in log earnings between the two periods as the outcome of interest in Equation (1). The setup corresponds to a model including lagged earnings as a control variable, with the coefficient of the lagged term restricted to unity. In this way, we incorporate a person fixed effect on the earnings level, and thus eliminate any bias due to sorting into downsizing/closure firms correlated with earnings. However, we do not eliminate bias due to sorting correlated with earnings growth. Hence, we may still need to control for observed characteristics in a flexible manner.

Table 7 presents the main results. Whether we consider earnings growth between years 0 and 3 , or average growth over the longer time intervals, we find that bankruptcy reduces earnings growth of native men by $0.21 \log$ point (see columns 1 and 2). The estimate is almost identical to what we found in the earnings level specifications in Table 6. This holds for all groups considered, regardless of gender and nativity, as well as for downsizing events. In other words, in the restricted sample of wages earners, exposure to bankruptcy or downsizing seems to be uncorrelated with (unobserved) time-invariant worker characteristics. 
Table 7. Job loss and earnings growth

\begin{tabular}{|c|c|c|c|c|c|c|}
\hline & $\begin{array}{c}\text { Year } 0 \text { to } \\
\text { year } 3 \\
(1)\end{array}$ & $\begin{array}{c}\text { Men } \\
\text { Base to post } \\
\text { period } \\
\text { (3-yr periods) } \\
(2) \\
\end{array}$ & $\begin{array}{l}\text { Placebo: } \\
\text { Pre to base } \\
\text { period (3-yr } \\
\text { periods) } \\
\text { (3) }\end{array}$ & $\begin{array}{c}\text { Year } 0 \text { to } \\
\text { year } 3 \\
(4)\end{array}$ & $\begin{array}{c}\text { Women } \\
\text { Base to post } \\
\text { period } \\
\text { (3-yr periods) } \\
(5)\end{array}$ & $\begin{array}{l}\text { Placebo: } \\
\text { Pre to base } \\
\text { period (3-yr } \\
\text { periods) } \\
\text { (6) }\end{array}$ \\
\hline \multicolumn{7}{|l|}{ A. Sample means } \\
\hline LDC immigrants & -0.139 & -0.127 & 0.306 & -0.208 & -0.210 & 0.487 \\
\hline EEA immigrants & 0.011 & 0.058 & 0.167 & -0.012 & 0.035 & 0.224 \\
\hline Natives & 0.033 & 0.084 & 0.138 & -0.006 & 0.041 & 0.195 \\
\hline \multicolumn{7}{|l|}{ B. Regression } \\
\hline Bankrupt & $\begin{array}{c}-0.208^{* * *} \\
(0.020)\end{array}$ & $\begin{array}{c}-0.207^{* * *} \\
(0.022)\end{array}$ & $\begin{array}{c}0.007 \\
(0.008)\end{array}$ & $\begin{array}{c}-0.323^{* * *} \\
(0.043)\end{array}$ & $\begin{array}{c}-0.241^{* * *} \\
(0.040)\end{array}$ & $\begin{array}{c}0.001 \\
(0.030)\end{array}$ \\
\hline LDC*bankrupt & $\begin{array}{c}-0.214^{* * *} \\
(0.058)\end{array}$ & $\begin{array}{c}-0.094 \\
(0.064)\end{array}$ & $\begin{array}{c}0.019 \\
(0.033)\end{array}$ & $\begin{array}{c}-0.116 \\
(0.136)\end{array}$ & $\begin{array}{c}-0.138 \\
(0.174)\end{array}$ & $\begin{array}{l}-0.015 \\
(0.047)\end{array}$ \\
\hline EEA*bankrupt & $\begin{array}{l}-0.008 \\
(0.045)\end{array}$ & $\begin{array}{l}-0.025 \\
(0.052)\end{array}$ & $\begin{array}{c}0.014 \\
(0.024)\end{array}$ & $\begin{array}{c}0.085 \\
(0.105)\end{array}$ & $\begin{array}{c}0.109 \\
(0.094)\end{array}$ & $\begin{array}{c}0.014 \\
(0.045)\end{array}$ \\
\hline Downsize & $\begin{array}{c}-0.056 * * * \\
(0.006)\end{array}$ & $\begin{array}{c}-0.064 * * * \\
(0.007)\end{array}$ & $\begin{array}{c}-0.002 \\
(0.003)\end{array}$ & $\begin{array}{c}-0.059 * * * \\
(0.010)\end{array}$ & $\begin{array}{c}-0.062 * * * \\
(0.012)\end{array}$ & $\begin{array}{c}0.006 \\
(0.006)\end{array}$ \\
\hline LDC*downsize & $\begin{array}{c}-0.106 * * * \\
(0.025)\end{array}$ & $\begin{array}{c}-0.059 * * \\
(0.028)\end{array}$ & $\begin{array}{c}0.005 \\
(0.015)\end{array}$ & $\begin{array}{c}-0.090 * \\
(0.047)\end{array}$ & $\begin{array}{c}-0.069 \\
(0.054)\end{array}$ & $\begin{array}{l}0.060 * \\
(0.019)\end{array}$ \\
\hline EEA*downsize & $\begin{array}{c}0.009 \\
(0.015)\end{array}$ & $\begin{array}{c}0.004 \\
(0.017)\end{array}$ & $\begin{array}{l}-0.011 \\
(0.008)\end{array}$ & $\begin{array}{c}0.028 \\
(0.024)\end{array}$ & $\begin{array}{c}0.010 \\
(0.029)\end{array}$ & $\begin{array}{l}-0.019 \\
(0.015)\end{array}$ \\
\hline Observations & 592686 & 469277 & 505109 & 267318 & 213081 & 226798 \\
\hline
\end{tabular}

$* * * / * * / *$ Statistically significant at $1 / 5 / 10$ percent level.

Note: Standard errors, clustered within individuals, are shown in parentheses. The dependent variable is the difference between log earnings in years 3 and 0 (cols 1 and 4); the difference between log cumulative earnings during the 3-year period following the year of any downsizing/bankruptcy and the 3-year period ending with the base year (cols 2 and 5); and that between log cumulative earnings during the 3-year period ending with the base year and the prior 3 -year period (cols 3 and 6). Samples and specifications are as described in notes to Tables 5 and 6 . Columns (3) and (6) additionally restrict samples to those at least age 25 and in the country five years before the base year.

Even so, exposure to bankruptcy or downsizing can be selective in the sense that workers on a less favorable experience profile with lower earnings growth may be more exposed to negative firm shocks. If this were true, we should expect to find that a future bankruptcy is associated with lower individual earnings growth even prior to the bankruptcy. To check this source of bias, we conduct a placebo test of whether earnings growth correlates with future exposure to bankruptcy or downsizing; see Table 7, columns (3) and (6). Recall that we condition the analysis sample on employment two years ahead of the firm shock, explaining the particularly high earnings growth prior to the base period for LDC 
immigrants (see panel A). The regression results reported in panel B reveal that earnings growth prior to the base period is not lower for those exposed to bankruptcy or downsizing. Indeed, there is no indication that our estimated effects showing lower earnings growth following job displacement are biased due to selective exposure. The only (slightly) significant pre-effect is found for LDC women employed in firms that downsize, taking a positive sign and suggesting that, in anything, for this group we may actually underestimate the adverse effect of job displacement.

\section{Heterogeneous effects of displacement by education}

The literature studying unemployment incidence and duration shows that highly educated individuals are less prone to experience unemployment and, if they do, have shorter spell durations than the less educated (see, e.g., Nickell, 1979; Røed and Zhang, 2005). Indeed, Hoynes et al. (2012) show that loweducation workers were more severely affected by the Great Recession than workers with high educational attainment. This raises the question of whether the more adverse effects of job displacement uncovered for LDC immigrants might simply be the reflection of their lower average attainment when compared to EEA immigrants and natives, and that, were we to compare workers with similar qualifications, there would be no differential effects of displacement across groups. (Recall that Table 4 showed that educational attainment among LDC immigrants is much lower than among natives and EEA immigrants.) In this section, we investigate this concern by augmenting the empirical models so that they allow for native and immigrant effects of bankruptcy and major downsizing events to differ by educational attainment. Results are presented in Table 8 (for the purpose of brevity, we focus on the effects found to be most significant in the prior section, namely those for natives and the differential effects for LDC immigrants).

Two sets of results stand out from the table. One is that the adverse consequences of job displacement indeed are most severe in the low-education bracket. To illustrate, bankruptcy reduces the future employment rate of less-educated native men by 6.6 percentage points, compared to 3.8 percentage points of those with medium attainment (high-school graduate but not completed college) and 3.0 percentage points among the highly educated (see col 1). Bankruptcy also reduces earnings growth of low-educated native workers at almost twice the rate of those with medium and high attainment 0.28 vs 0.17 log point; see col 3). Columns 4-6 reveal similar, if not stronger, patterns for native women and, when we study the effects of major downsizings on future employment and earnings, we find a strikingly consistent pattern of larger effects for less-educated natives compared to the highly educated. 
Table 8. Effects of bankruptcy and downsizing on employment and earnings by educational attainment

\begin{tabular}{|c|c|c|c|c|c|c|}
\hline & \multicolumn{3}{|c|}{ Men } & \multicolumn{3}{|c|}{ Women } \\
\hline & $\begin{array}{c}\text { Employ- } \\
\text { ment } \\
(1)\end{array}$ & $\begin{array}{c}\text { Ln(earnings) } \\
(2)\end{array}$ & $\begin{array}{c}\text { Earnings } \\
\text { growth } \\
(3) \\
\end{array}$ & $\begin{array}{c}\text { Employ- } \\
\text { ment } \\
(4)\end{array}$ & $\begin{array}{c}\text { Ln(earnings) } \\
(5)\end{array}$ & $\begin{array}{c}\text { Earnings } \\
\text { growth } \\
(6) \\
\end{array}$ \\
\hline \multicolumn{7}{|l|}{ A. Bankrupt } \\
\hline Low education & $\begin{array}{c}-0.066 * * * \\
(0.012)\end{array}$ & $\begin{array}{c}-0.297 * * * \\
(0.040)\end{array}$ & $\begin{array}{c}-0.280 * * * \\
(0.039)\end{array}$ & $\begin{array}{c}-0.114^{* * *} \\
(0.023)\end{array}$ & $\begin{array}{c}-0.399 * * * \\
(0.068)\end{array}$ & $\begin{array}{c}-0.397 * * * \\
(0.066)\end{array}$ \\
\hline Medium educ & $\begin{array}{c}-0.038 * * * \\
(0.008)\end{array}$ & $\begin{array}{c}-0.192^{* * *} \\
(0.024)\end{array}$ & $\begin{array}{c}-0.167^{* * *} \\
(0.025)\end{array}$ & $\begin{array}{c}-0.076 * * * \\
(0.023)\end{array}$ & $\begin{array}{c}-0.359 * * * \\
(0.074)\end{array}$ & $\begin{array}{c}-0.322 * * * \\
(0.073)\end{array}$ \\
\hline High educ & $\begin{array}{c}-0.030 * * \\
(0.014)\end{array}$ & $\begin{array}{c}-0.272 * * * \\
(0.051)\end{array}$ & $\begin{array}{c}-0.178 * * * \\
(0.050)\end{array}$ & $\begin{array}{l}-0.041 \\
(0.026)\end{array}$ & $\begin{array}{c}-0.147^{*} \\
(0.080)\end{array}$ & $\begin{array}{l}-0.120 \\
(0.077)\end{array}$ \\
\hline LDC*low educ & $\begin{array}{c}-0.087 * * * \\
(0.033)\end{array}$ & $\begin{array}{c}-0.218^{* *} \\
(0.096)\end{array}$ & $\begin{array}{c}-0.177^{*} \\
(0.093)\end{array}$ & $\begin{array}{l}-0.061 \\
(0.061)\end{array}$ & $\begin{array}{c}-0.400 * \\
(0.232)\end{array}$ & $\begin{array}{l}-0.268 \\
(0.220)\end{array}$ \\
\hline LDC*med educ & $\begin{array}{l}-0.054^{*} \\
(0.030)\end{array}$ & $\begin{array}{c}-0.185^{* *} \\
(0.083)\end{array}$ & $\begin{array}{c}-0.175^{* *} \\
(0.081)\end{array}$ & $\begin{array}{l}-0.048 \\
(0.078)\end{array}$ & $\begin{array}{c}0.226 \\
(0.175)\end{array}$ & $\begin{array}{c}0.147 \\
(0.181)\end{array}$ \\
\hline LDC*high educ & $\begin{array}{c}-0.104^{* *} \\
(0.048)\end{array}$ & $\begin{array}{l}-0.219 \\
(0.160)\end{array}$ & $\begin{array}{c}-0.319 * * \\
(0.157)\end{array}$ & $\begin{array}{c}0.031 \\
(0.068)\end{array}$ & $\begin{array}{l}-0.056 \\
(0.166)\end{array}$ & $\begin{array}{c}0.004 \\
(0.141)\end{array}$ \\
\hline B. Downsize & & & & & & \\
\hline Low education & $\begin{array}{c}-0.022^{* * *} \\
(0.004)\end{array}$ & $\begin{array}{c}-0.102^{* * *} \\
(0.014)\end{array}$ & $\begin{array}{c}-0.086 * * * \\
(0.013)\end{array}$ & $\begin{array}{c}-0.019 * * * \\
(0.005)\end{array}$ & $\begin{array}{c}-0.055^{* * *} \\
(0.017)\end{array}$ & $\begin{array}{c}-0.065^{* * * *} \\
(0.016)\end{array}$ \\
\hline Medium educ & $\begin{array}{c}-0.014^{* * *} \\
(0.003)\end{array}$ & $\begin{array}{c}-0.082^{* * *} \\
(0.010)\end{array}$ & $\begin{array}{c}-0.054 * * * \\
(0.009)\end{array}$ & $\begin{array}{c}-0.012 * * \\
(0.006)\end{array}$ & $\begin{array}{c}-0.064 * * * \\
(0.019)\end{array}$ & $\begin{array}{c}-0.067^{* * * *} \\
(0.018)\end{array}$ \\
\hline High educ & $\begin{array}{c}-0.007^{* * *} \\
(0.003)\end{array}$ & $\begin{array}{c}-0.059 * * * \\
(0.011)\end{array}$ & $\begin{array}{c}-0.023 * * \\
(0.009)\end{array}$ & $\begin{array}{l}-0.004 \\
(0.005)\end{array}$ & $\begin{array}{c}-0.053^{* *} \\
(0.022)\end{array}$ & $\begin{array}{l}-0.033 \\
(0.021)\end{array}$ \\
\hline LDC*low educ & $\begin{array}{c}-0.061 * * * \\
(0.014)\end{array}$ & $\begin{array}{c}-0.160 * * * \\
(0.046)\end{array}$ & $\begin{array}{c}-0.186 * * * \\
(0.046)\end{array}$ & $\begin{array}{c}-0.067^{* * *} \\
(0.024)\end{array}$ & $\begin{array}{l}-0.073 \\
(0.070)\end{array}$ & $\begin{array}{l}-0.099 \\
(0.071)\end{array}$ \\
\hline LDC*med educ & $\begin{array}{l}-0.008 \\
(0.012)\end{array}$ & $\begin{array}{c}-0.005 \\
(0.037)\end{array}$ & $\begin{array}{c}-0.175^{* *} \\
(0.081)\end{array}$ & $\begin{array}{c}-0.059 * * \\
(0.026)\end{array}$ & $\begin{array}{l}-0.119 \\
(0.086)\end{array}$ & $\begin{array}{l}-0.116 \\
(0.084)\end{array}$ \\
\hline LDC*high educ & $\begin{array}{l}-0.026^{*} \\
(0.015)\end{array}$ & $\begin{array}{l}-0.022 \\
(0.043)\end{array}$ & $\begin{array}{l}-0.026 \\
(0.043)\end{array}$ & $\begin{array}{l}-0.018 \\
(0.027)\end{array}$ & $\begin{array}{c}0.003 \\
(0.092)\end{array}$ & $\begin{array}{l}-0.026 \\
(0.087)\end{array}$ \\
\hline Observations & 597719 & 591896 & 591896 & 270816 & 267022 & 267022 \\
\hline
\end{tabular}

$* * * / * * / *$ Statistically significant at $1 / 5 / 10$ percent level.

Note: Standard errors, clustered within individuals, are shown in parentheses. Dependent variable in cols (1) and (4) is employment in year 3; in cols (2) and (5) log earnings in year 3; and that in cols (3) and (6) the difference between log earnings in year 3 and the base year. Samples and specifications are described in notes to Tables 5 and 6. As in those tables, all regressions also include interaction terms between bankrupt/downsize and EEA immigrant. 
Second, the results in Table 8 confirm generally larger effects of job displacement for immigrants from LDC countries than for native workers. This is particularly true in the low-education bracket where displacement effects on future employment and earnings are quite similar to those for the full sample reported in Table 5 through Table 7. Importantly, even when we restrict attention to workers who did not complete high school, the adverse effects of bankruptcy and major downsizing events are more severe for immigrants from poor source countries than for native workers. For male workers, the negative employment effects of a job loss are more severe for LDC immigrants within all three education groups.

\section{Regression analysis of migration decisions}

Job loss arising from bankruptcy and downsizing are likely to trigger regional mobility (Huttunen et al, 2015). For migrants who become unemployed, returning to their country of origin represents a relevant alternative (Bijwaard et al, 2014). Evidence on migration responses is important for assessment of the overall welfare and fiscal consequences of structural change and job loss, as migrants may leave the country and the pool of eligible social insurance claimants (Kirdar, 2012). Results presented so far have been based on the populations that remain in Norway through the various outcome periods following any job displacement, and a concern is that our estimates may be driven by selective migration responses. For example, if employer bankruptcy triggers outmigration of those with the highest earnings potential, the remaining group will be negatively selected and the adverse effect of bankruptcy on future labor market outcomes would appear to be larger than the true effect.

In Table 9, we study migration abroad and moves to other labor market regions within Norway, using separate linear probability regression models where indicators for outmigration and (conditional on no outmigration) regional migration by the end of year $t+3$ are the dichotomous outcome variables. Looking first at the sample means reported in panel A, we note that LDC migrants have very low outmigration rates. As in the overall samples (refer back to Table 3), outmigration rates are about five times higher among EEA migrants compared to LDC migrants, despite the much lower outmigration propensities in the restricted analysis samples. Only three in one thousand native workers emigrate within the 3-year period.

Our focus is on the effects of job displacement and the regression results in panel B show that, when it comes to outmigration, only EEA immigrants are affected. Consequently, selective outmigration responses cannot explain our findings that LDC workers have less favorable labor market outcomes following employer bankruptcy or downsizing. 
Table 9. Migration and mobility following bankruptcy or downsizing

\begin{tabular}{|c|c|c|c|c|}
\hline & \multicolumn{2}{|c|}{ Outmigration } & \multicolumn{2}{|c|}{ Mobility between labor market regions } \\
\hline & $\begin{array}{c}\text { Men } \\
(1) \\
\end{array}$ & $\begin{array}{c}\text { Women } \\
(2)\end{array}$ & $\begin{array}{c}\text { Men } \\
(3) \\
\end{array}$ & $\begin{array}{c}\text { Women } \\
(4)\end{array}$ \\
\hline \multicolumn{5}{|l|}{ A. Sample means } \\
\hline LDC immigrants & 0.008 & 0.006 & 0.027 & 0.025 \\
\hline EEA immigrants & 0.051 & 0.052 & 0.029 & 0.027 \\
\hline Natives & 0.003 & 0.003 & 0.031 & 0.030 \\
\hline \multicolumn{5}{|l|}{ B. Regression coeffs } \\
\hline Bankrupt & $\begin{array}{c}0.000 \\
(0.001)\end{array}$ & $\begin{array}{c}-0.003 * * * \\
(0.000)\end{array}$ & $\begin{array}{c}0.007 \\
(0.005)\end{array}$ & $\begin{array}{c}0.010 \\
(0.009)\end{array}$ \\
\hline LDC*bankrupt & $\begin{array}{c}0.000 \\
(0.005)\end{array}$ & $\begin{array}{c}-0.008^{* *} \\
(0.003)\end{array}$ & $\begin{array}{c}0.017 \\
(0.012)\end{array}$ & $\begin{array}{c}-0.023 \\
(0.014)\end{array}$ \\
\hline EEA* bankrupt & $\begin{array}{c}0.026 * * * \\
(0.012)\end{array}$ & $\begin{array}{c}0.037 \\
(0.025)\end{array}$ & $\begin{array}{c}-0.010 \\
(0.010)\end{array}$ & $\begin{array}{c}0.008 \\
(0.021)\end{array}$ \\
\hline Downsize & $\begin{array}{c}0.001 \\
(0.001)\end{array}$ & $\begin{array}{c}0.001 \\
(0.001)\end{array}$ & $\begin{array}{c}0.002 \\
(0.002)\end{array}$ & $\begin{array}{c}0.000 \\
(0.003)\end{array}$ \\
\hline LDC*downsize & $\begin{array}{c}-0.001 \\
(0.002)\end{array}$ & $\begin{array}{c}0.005 \\
(0.004)\end{array}$ & $\begin{array}{c}0.004 \\
(0.005)\end{array}$ & $\begin{array}{c}-0.008 \\
(0.006)\end{array}$ \\
\hline EEA*downsize & $\begin{array}{c}0.015^{* * *} \\
(0.006)\end{array}$ & $\begin{array}{c}0.000 \\
(0.007)\end{array}$ & $\begin{array}{c}0.003 \\
(0.005)\end{array}$ & $\begin{array}{c}0.008 \\
(0.006)\end{array}$ \\
\hline Ln(earnings base period) & $\begin{array}{c}0.008 * * * \\
(0.001)\end{array}$ & $\begin{array}{c}0.003^{* * *} \\
(0.001)\end{array}$ & $\begin{array}{c}-0.007^{* * * *} \\
(0.001)\end{array}$ & $\begin{array}{l}-0.002 \\
(0.002)\end{array}$ \\
\hline LDC*In(earnings) & $\begin{array}{c}0.019 * * * \\
(0.002)\end{array}$ & $\begin{array}{c}0.018^{* * *} \\
(0.003)\end{array}$ & $\begin{array}{l}-0.003 \\
(0.003)\end{array}$ & $\begin{array}{c}0.001 \\
(0.004)\end{array}$ \\
\hline $\mathrm{EEA}^{*} \ln ($ earnings) & $\begin{array}{c}0.025 * * * \\
(0.003)\end{array}$ & $\begin{array}{c}0.002 \\
(0.003)\end{array}$ & $\begin{array}{c}0.000 \\
(0.002)\end{array}$ & $\begin{array}{c}-0.004 \\
(0.002)\end{array}$ \\
\hline Bankrupt*In(earnings) & $\begin{array}{c}0.002 \\
(0.005)\end{array}$ & $\begin{array}{l}-0.001 \\
(0.001)\end{array}$ & $\begin{array}{c}0.012 \\
(0.015)\end{array}$ & $\begin{array}{c}0.054 * * \\
(0.027)\end{array}$ \\
\hline LDC*bankrupt*In(earnings) & $\begin{array}{l}-0.010 \\
(0.015)\end{array}$ & $\begin{array}{c}0.000 \\
(0.007)\end{array}$ & $\begin{array}{c}0.039 \\
(0.033)\end{array}$ & $\begin{array}{c}-0.061 * \\
(0.033)\end{array}$ \\
\hline EEA*bankrupt*In(earnings) & $\begin{array}{l}-0.009 \\
(0.028)\end{array}$ & $\begin{array}{c}-0.135^{*} \\
(0.072)\end{array}$ & $\begin{array}{c}0.000 \\
(0.023)\end{array}$ & $\begin{array}{c}0.005 \\
(0.058)\end{array}$ \\
\hline Downsize*In(earnings) & $\begin{array}{c}0.002 \\
(0.002)\end{array}$ & $\begin{array}{c}0.002 \\
(0.002)\end{array}$ & $\begin{array}{l}-0.002 \\
(0.005)\end{array}$ & $\begin{array}{l}-0.007 \\
(0.007)\end{array}$ \\
\hline LDC*downsize* $\ln ($ earnings) & $\begin{array}{l}-0.006 \\
(0.009)\end{array}$ & $\begin{array}{l}-0.004 \\
(0.011)\end{array}$ & $\begin{array}{l}-0.013 \\
(0.018)\end{array}$ & $\begin{array}{c}0.002 \\
(0.014)\end{array}$ \\
\hline EEA*downsize* $\ln ($ earnings) & $\begin{array}{l}-0.006 \\
(0.013)\end{array}$ & $\begin{array}{c}0.008 \\
(0.018)\end{array}$ & $\begin{array}{l}-0.020^{*} \\
(0.012)\end{array}$ & $\begin{array}{l}-0.007 \\
(0.014)\end{array}$ \\
\hline Observations & 605021 & 274128 & 598003 & 270938 \\
\hline
\end{tabular}

$* * * / * * / *$ Statistically significant at $1 / 5 / 10$ percent level.

Note: Standard errors, clustered within individuals, are shown in parentheses. The dependent variable in cols (1) and (2) is an indicator for whether or not the worker outmigrated, and that in cols (3) and (4) whether the worker moved between labor market regions during the 3-year period following the base year. Samples and additional control variables are as described in notes to Table 5, with the exception that columns (1) and (2) also include those who outmigrated between the base year and year $t_{0}+3$. Main and two-way interaction effects are evaluated at gender-specific sample mean of log earnings in base period. 
The outmigration rate of male EEA immigrants increases by about 40 percent relative to the sample mean in response to employer bankruptcy, while the effect of downsizing is a 20 percent boost in the outmigration rate (see column 1). Among EEA women, we find a similar effect of bankruptcy, but no effect of downsizing. Table 9 also reveals that outmigration in general is indeed selective as those with high earnings in the base period are significantly more likely to leave the country than those with low earnings. This pattern could potentially explain why EEA workers who remained had less favorable outcomes (as for this group there is a relationship between job loss and outmigration). However, when we test whether those who leave closing and downsizing firms differ from other leavers in terms of preperiod earnings, the coefficients of the three-way interaction terms between immigrant group, firm shock and pre-period earnings are virtually zero and statistically insignificant for almost every group considered. The single exception is EEA women working in bankruptcy firms, for whom we find a negative interaction effect between bankruptcy and pre-period earnings on outmigration (see col 2), hinting that the bankruptcy effect estimates on employment and earnings may be impaired by positive bias. In fact, this conjecture is consistent with the pattern of positive interaction effects of bankruptcy on employment and earnings of EEA women shown in Tables 5 through 7. For EEA women, our estimates likely understate the adverse effects of job displacement. For all other groups, there is no indication that our estimates, based on those who stay in the country, are biased due to selective outmigration.

The findings of the prior section that the adverse employment effects of job loss are particularly large for LDC immigrants might appear surprising in light of existing evidence that immigrants in general are more mobile than natives and more readily move to regions with job vacancies (see, e.g., Røed and Schøne, 2012). Table 9 reveals that overall mobility between labor market regions in the restricted sample is very similar across groups (see panel A, cols 3 and 4), although Table 3 showed higher mobility for both immigrant groups than for natives in the overall sample. When it comes to mobility effects of bankruptcy, there is no indication of a native response. Regional mobility decisions among male LDC immigrants, however, are somewhat more sensitive to job loss than what is the case for natives. According to the estimates in column (3), employer bankruptcy raises the probability of moving to another labor market region for an LDC male by 2.4 percentage points $(0.007+0.017)$, roughly equal in size to their average mobility rate. For women, we find no indication that a major downsizing has any effect on outmigration or mobility across domestic regions. In sum, male LDC immigrants are more mobile than natives following job loss, but even if such improved mobility is expected to mitigate any 
adverse effects of displacement, its impact appears to be dominated by other factors leading to the less favorable labor market outcomes observed among immigrants from low-income countries.

\section{Job loss and future employment and earnings}

Our main objective has been to estimate causal effects of job loss by means of firm employment shocks, and we have shown that immigrants from low-income source countries are both more exposed to and suffer more severe consequences of these events. Such evidence suggests that bankruptcies and major downsizing events should account for a significant portion of the observed differences in employment and earnings between LDC immigrants and natives. Since these events are so rare, however, their potential for explaining major parts of employment and earnings gaps is rather limited.

More importantly, our evidence speaks to the effects of job loss in general. Previous studies of job separations and transitions out of employment suggest that immigrants are more prone to experience termination of job spells, even in cases where firms survive and do not downsize dramatically (see, e.g., Bratsberg et al., 2010; Barth et al., 2012). Typically, job spell data, and those drawn from administrative registers in particular, cannot separate voluntary termination of spells from involuntary job loss. In lack of direct measures, we therefore estimate job loss rates of the various worker groups by combining information on inflows into unemployment and firm shock status.

The data underlying Figure 3 reveal that 44.2 percent of natives in firms that went bankrupt in year $t+2$ had an unemployment incidence in year $t+1$ or year $t+2$. Since we know that all workers in bankrupt firms actually lose their job, these figures indicate that one in two displaced native workers find a new job or leave the labor market without an intermittent spell of unemployment. ${ }^{5}$ Table 10 , row $A$, reports such rates for the various groups considered, showing that inflow rates from bankruptcy to registered unemployment range from 36.1 percent among EEA women to 55.3 percent among LDC men. Next, using information on flows from employment into unemployment for all workers, including those in "stable" firms, we derive an estimate of the overall job loss rate by dividing the (group-specific) inflow rate into registered unemployment (see row $\mathrm{B}$ ) by the inflow rate among workers who experienced employer bankruptcy. Following this logic, Table 10, row C, reports estimated job loss rates across groups. While native men have an estimated job loss probability of 9.8 percent, the rate is 22.3 percent for male LDC immigrants. Immigrant men from the EEA are slightly more exposed than natives (12.3

\footnotetext{
${ }^{5}$ We miss very short unemployment spells as data are registrations by the end of each calendar month.
} 
percent). Women are more exposed to job loss than men, but the immigrants-native differentials are similar by gender. Finally, row E reports estimated job loss rates for workers in "stable" firms, showing that even in this group displacement is frequent with job loss rates ranging from 9.2 percent for native men to 30.3 percent for female LDC immigrants.

Table 10. Estimated job loss rates

\begin{tabular}{|c|c|c|c|c|c|c|}
\hline & $\begin{array}{l}\text { LDC imm } \\
\text { (1) }\end{array}$ & $\begin{array}{c}\text { Men } \\
\text { EEA imm } \\
\text { (2) }\end{array}$ & $\begin{array}{c}\text { Native } \\
\text { (3) }\end{array}$ & $\begin{array}{c}\text { LDC imm } \\
(4)\end{array}$ & $\begin{array}{c}\text { Women } \\
\text { EEA imm } \\
(5)\end{array}$ & $\begin{array}{c}\text { Native } \\
\text { (6) }\end{array}$ \\
\hline A. Reg unemployment from bankruptcy & 0.553 & 0.450 & 0.442 & 0.444 & 0.361 & 0.419 \\
\hline B. Registered unemployment, all & 0.123 & 0.055 & 0.043 & 0.138 & 0.059 & 0.054 \\
\hline C. Estimated overall job loss rate B/A & 0.223 & 0.123 & 0.098 & 0.312 & 0.162 & 0.128 \\
\hline D. Reg unemployment from stable firms & 0.118 & 0.052 & 0.041 & 0.135 & 0.056 & 0.051 \\
\hline E. Est job loss rate stable firms D/A & 0.213 & 0.115 & 0.092 & 0.303 & 0.156 & 0.122 \\
\hline
\end{tabular}

To proceed, we also need estimates of the causal effect of job loss by group. The estimated effects of bankruptcy on employment change and earnings growth from Tables 5 and 7 provide a natural basis. These numbers suffer, however, from contamination bias since, as Table 10 showed, some workers in the comparison group of stable firms also experienced job loss over the period. To correct for such bias, we follow Bratsberg et al. (2013) and divide the effect estimates from Tables 5 and 7 by one minus the job loss rate from stable firms computed in Table 10, row E. For example, with a job loss rate of 10 percent from stable firms, we adjust for contamination bias by dividing the effect estimate by 0.9. As job loss rates differ across groups, this adjustment will be group specific and the resulting job loss effect estimates are reported in Table 11, row B for LDC immigrants and row D for native workers.

With overall job loss rates and effect estimates adjusted for contamination bias in hand, we next calculate the contribution of job loss to the observed differences in employment change and earnings growth between immigrants and natives. As in standard decomposition exercises, the relative contributions of differences in effects and exposure rates depend on the arbitrary choice between two alternative sets of weights. For this reason, we use the (unweighted) average of the two sets of weights 
Table 11. Accounting for job loss effects on change in employment and log earnings, LDC immigrants vs. natives

\begin{tabular}{|c|c|c|c|c|}
\hline & \multicolumn{2}{|c|}{ Employment change } & \multicolumn{2}{|c|}{ Log earnings growth } \\
\hline & $\begin{array}{c}\text { Men } \\
(1)\end{array}$ & $\begin{array}{c}\text { Women } \\
(2)\end{array}$ & $\begin{array}{c}\text { Men } \\
(3) \\
\end{array}$ & $\begin{array}{c}\text { Women } \\
(4)\end{array}$ \\
\hline A. Imm bankruptcy effect from Tables 5/7 & -0.127 & -0.131 & -0.422 & -0.439 \\
\hline B. Adjusted imm job loss effect $A /(1-10 E)$ & -0.161 & -.0188 & -0.537 & -0.630 \\
\hline C. Native bankruptcy effect from Tables 5/7 & -0.046 & -0.088 & -0.209 & -0.323 \\
\hline D. Adjusted native job loss effect $C /(1-10 E)$ & -0.051 & -0.101 & -0.230 & -0.368 \\
\hline E. Imm-native effect diff*average job loss rate & -0.018 & -0.019 & -0.049 & -0.058 \\
\hline F. Job loss diff*average effect & -0.013 & -0.027 & -0.048 & -0.092 \\
\hline G. Explained imm-native diff $E+F$ & -0.031 & -0.046 & -0.097 & -0.150 \\
\hline H. Observed imm-native diff Tables 5/7 & -0.058 & -0.078 & -0.172 & -0.202 \\
\hline I. Percent explained $100 * \mathrm{G} / \mathrm{H}$ & 53.2 & 58.6 & 56.4 & 74.3 \\
\hline
\end{tabular}

in evaluating the size of these components. Focusing on the total contributions, we find that, for male immigrant workers from LDC countries, 53.2 percent of the employment gap relative to natives in year $t+3$ can be attributed to differential exposure to and effects of job loss during the two previous years (see row I). For women, job loss accounts for almost 60 percent of the observed employment differential. Similarly, differences in exposure to and effects of job loss explain fully 56 percent of immigrant-native differential earnings growth among men and 74 percent among women. For men, the decomposition exercise shows that differences in effects of job loss are slightly more important than differences in job loss rates in explaining differential employment change and earnings growth between immigrants and natives. Conversely, for women we find that differences in exposure rates are more important than differences in effects of job loss. Nonetheless, the more important lesson to be learned from the decomposition exercise is that a major portion of the inferior labor market developments of immigrant workers from low-income source countries relative to natives stems from their differential job loss experiences. 


\section{Conclusion}

In order to ensure lasting labor market integration of immigrants from developing countries, it may not be sufficient to facilitate successful labor market entry. The starting point of this paper was that the labor market performance of immigrants from low-income source countries falls below that of natives across European host countries. Although there is a strong process of labor market assimilation for most immigrant groups during the first years after arrival, we have seen a disturbing tendency for this process to lose steam, and even go into reverse well before reaching employment parity with natives.

Based on administrative longitudinal data from Norway, we have shown in this paper that involuntary transitions out of employment are more frequent among immigrants from developing countries. In particular, LDC immigrants are much more exposed to adverse employment shocks hitting their employer than (similar) natives are. Based on examinations of future outcomes for workers in firms that closed down due to bankruptcy, we also show that the consequences of such shocks - in terms of subsequent employment and earnings paths - are more severe for LDC immigrants than for native-born workers.

An important reason why immigrants from developing countries are more likely than other workers to leave employment is that they tend to work in precarious firms, with high risks of experiencing a downsizing or closure event in the near future. The overexposure of LDC immigrants to such events is approximately 50 percent. Moreover, LDC immigrants typically have short job tenure and relatively low (and inflexible) qualifications, making them more likely to be selected for layoff during downsizing and reorganization processes. Overall, we estimate that the job loss rate of LDC immigrants is more than twice that of native workers.

It is less obvious why the individual consequences of job loss are found to be more severe for immigrants than for natives. One probable explanation is that upon job loss, the lack of general skills, including fluency in the native language, forms a barrier in the search for new employment. This interpretation is consistent with our finding that adverse consequences of a job loss are most severe for workers with low educational attainment. In particular, the most negative employment effects of job loss are identified for LDC immigrants without a high-school degree. Skills may also interact with the social insurance system, as its progressive nature implies relatively high benefit replacement rates for persons with low potential labor earnings, contributing to lower return rates to employment among immigrants hit by job displacement. 
Although we estimate the impacts of job loss on the basis of the relatively rare events of firm bankruptcy, we extrapolate our findings to the labor market as a whole. This extrapolation is based on the additional assumption that, within each demographic group, a given fraction of displaced workers will register as unemployed job seekers, implying that we can back out the total number of involuntary job losses from observed rates of registered unemployment. We then find that more than 50 percent of the elevated probability of leaving employment among immigrants can be attributed to the combination of higher involuntary job loss rates and more severe effects of job loss.

Our results show that lack of job stability and the more frequent transitions out of employment contribute importantly to the explanation why immigrants fail to integrate fully in the host-country labor market. For the rising rates of immigration to represent a solution to - rather than an aggravation of the fiscal challenges facing many developed nations, integration efforts therefore need to have a longterm perspective, securing robust labor market attachment over the life course. Our findings point to the necessity of greater policy focus on integration efforts in relation to early immigrant job loss; e.g., in terms of activation and language skills enhancement. 


\section{References}

Aydemir, A., and Skuterud, M. (2008) The Immigrant Wage Differential within and across Establishments, Industrial and Labor Relations Review, Vol 61, No.3, pp. 334-352.

Barth, E., Bratsberg, B., and Raaum, O. (2004) Identifying Earnings Assimilation of Immigrants under Changing Macroeconomic Conditions. Scandinavian Journal of Economics, vol. 106(1), pp. 1-22.

Barth, E., Bratsberg, B., and Raaum, O. (2012) Immigrant Wage Profiles within and between Firms. Labour Economics, vol. 19(4), pp. 541-556.

Bhuller, M.S. (2009) Inndeling av Norge i arbeidsmarkedsregioner, Notater 2009/24, Statistics Norway.

Bijwaard, G. E., Schluter, C., \& Wahba, J. (2014) The impact of labor market dynamics on the return migration of immigrants. Review of Economics and Statistics, 96(3), 483-494.

Bleakley, H., and Chin, A. (2004) Language Skills and Earnings: Evidence from Childhood Immigrants. Review of Economics and Statistics 86(2):481-96.

Boeri, T. (2010) Immigration to the Land of Redistribution. Economica, vol. 77(308), pp. 651-87.

Bratsberg, B., Barth, E., and Raaum, O. (2006), Local Unemployment and the Relative Wages of Immigrants: Evidence from the Current Population Surveys, Review of Economics and Statistics, Vol. 88, No. 2, 243-263.

Bratsberg, B, Fevang, E., and Røed, K. (2013) Job Loss and Disability Insurance. Labour Economics, vol. 24, pp. 137-150.

Bratsberg, B., Raaum, O., and Røed, K. (2010) When Minority Labor Migrants Meet the Welfare State. Journal of Labor Economics, vol. 28, No. 3, pp. 633-676.

Bratsberg, B., Raaum, O., and Røed, K. (2014) Immigrants, Labour Market Performance, and Social Insurance. The Economic Journal. vol. 124, No. 580, pp. F644-F683.

Card, D., Heining, J., and Kline, P. (2013) Workplace Heterogeneity and the Rise of West Germany Wage Inequality, The Quarterly Journal of Economics, vol. 128(3), pp 967-1015.

Carlsson, M., and Rooth, D.-O. (2007) Evidence of Ethnic Discrimination in the Swedish Labor Market Using Experimental Data. Labour Economics 14(4), 716-729. 
Couch, K.A. and Placzek, D.W. (2010) Earnings Losses of Displaced Workers Revisited, American Economic Review 100 (1), pp. 572-589.

Dustmann, C., Glitz, A., Schönberg,U., and Bruecker, H. (2015) Referral-based Job Search Networks. Review of Economic Studies, forthcoming.

Dustmann, C., Glitz, A., and Vogel, T. (2010) Employment, Wages, and the Economic Cycle: Differences between Immigrants and Natives. European Economic Review, vol. 54(1), pp. 1-17.

Ferrer, A., Green, D.A., and Riddell, W.C. (2006) The Effect of Literacy on Immigrant Earnings. Journal of Human Resources, Vol. 41(2), pp. 380-410.

Hallock, K. F. (2009) Job Loss and the Fraying of the Implicit Employment Contract. Journal of Economic Perspectives, vol. 23(4), pp. 69-93.

Hamermesh, D. (1987) The Costs of Worker Displacement. Quarterly Journal of Economics, vol. 102(1), pp. 51-76.

Hoynes, H., Miller, D.L., and Schaller, J. (2012) Who Suffers During Recessions? Journal of Economic Perspectives, Vol.26, No.3, pp. 27-47.

Huttunen, K., Møen, J., and Salvanes, K.G. (2011) How Destructive is Creative Destruction? Effects of Job Loss on Mobility, Withdrawal and Income. Journal of the European Economic Association, 9(5), pp. $840-870$.

Huttunen, K., Møen, J., and Salvanes, K.G. (2015) Job Loss and Regional Mobility, IZA DP No 8780.

Jacobson, L.S., Lalonde, J.T., and Sullivan, D.G. (1993) Earnings Losses of Displaced Workers. American Economic Review 83(4), 685-709.

Kirdar, M.G. (2012) Estimating the impact of immigrants on the host country social security system when return migration is an endogenous choice, International Economic Review, Vol 53. No.2 (2012), 453-486.

Kletzer, L.G. (1998) Job Displacement. Journal of Economic Perspectives, vol. 12(1), pp. 115-136.

Neal, D. (1995) Industry-Specific Human Capital: Evidence from Displaced Workers. Journal of Labor Economics, vol. 13(4), pp. 653-677. 
Nickell, S. (1979) Education and Lifetime Patterns of Unemployment. Journal of Political Economy, vol. 87(5), pp. S117-S131.

OECD (2015a) Migration Policy Debates, No. 8, November 2015.

OECD (2015b), Indicators of Immigrant Integration 2015: Settling In. OECD/European Union.

Rege, M., Telle, K., and Votruba, M. (2009) The Effect of Plant Downsizing on Disability Pension Utilization. Journal of the European Economic Association, vol. 7(5), pp. 754-785.

Rege, M., Telle, K., and Votruba, M. (2011) Parental job loss and children's school performance. Review of Economic Studies, 78(4), 1462-1489.

Røed, K., and Zhang, T. (2005). Unemployment duration and economic incentives-a quasi randomassignment approach. European Economic Review, vol. 49(1), pp. 1-17.

Røed, M., and Schøne, P. (2012) Does immigration increase labour market flexibility? Labour Economics, 19(4), 527-540.

Ruhm, C. J. (1991) Are Workers Permanently Scarred by Job Displacements? The American Economic Review, vol. 81(1), pp. 319-324.

Salvanes, K.G. (1997) Market Rigidities and Labour Market Flexibility: An International Comparison. The Scandinavian Journal of Economics, vol. 99(2), pp. 315-333.

Trejo, S. (2003) Intergenerational Progress of Mexican-Origin Workers in the U.S. Labor Market, Journal of Human Resources, 38(3): 467-489. 
Appendix Table A-1. Estimated effects of bankruptcy and downsizing on employment and earnings without controlling for individual characteristics

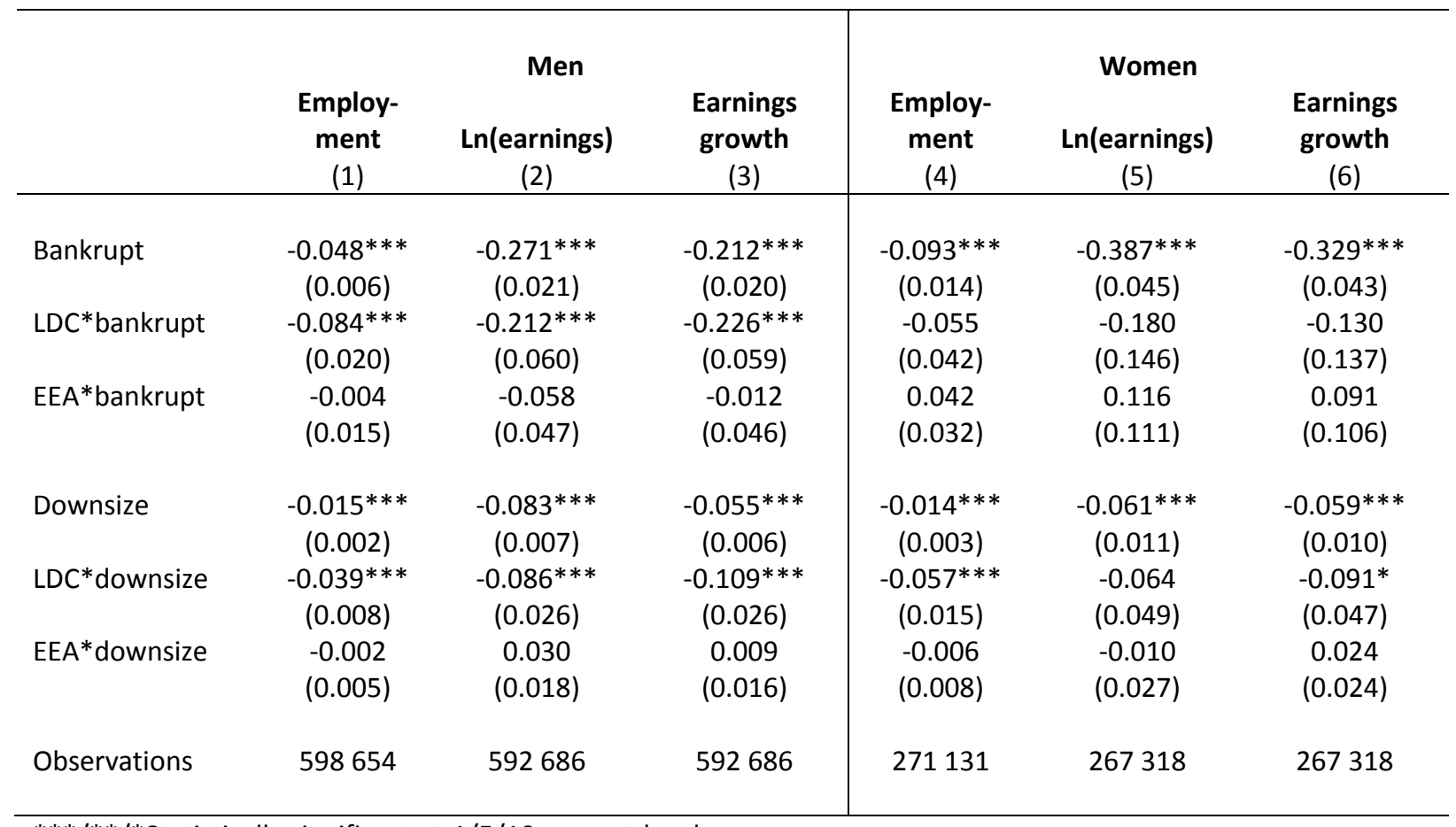

$* * * / * * / *$ Statistically significant at $1 / 5 / 10$ percent level.

Note: Standard errors, clustered within individuals, are shown in parentheses. Specifications control for year and 2-digit industry. See also notes to tables 5, 6 and 7. 